\title{
3. Model diet for a living wage
}

\section{PART I. BACKGROUND}

In low income countries, on average, around $48 \%$ of all expenditures are for food, and in lower middle income countries, on average, around 37\% of all expenditures are for food (Anker, 2011a). Therefore, estimating food costs is necessarily a very important part of estimating a living wage. The estimate of food costs for a living wage should be sufficient for workers and their families to afford a nutritious, palatable diet.

The approach used in our methodology to estimate food costs is to first create a model diet that meets WHO recommendations on nutrition, is consistent with local food preferences, and is relatively low in cost for a nutritious diet. The cost of the model diet is then estimated using local food prices determined through a local market survey that mimics the ways in which cost-conscious workers shop for food.

Developing a new approach was necessary for estimating food costs because suitable model diets for a living wage are not available in most countries. Although model diets exist for many countries, they have usually been developed for other purposes and generally are not appropriate for estimating food costs for a living wage. Model diets used to estimate national poverty lines are based on observed food consumption of households that consume the required number of calories, so they include sufficient calories by design. However, they do not concern themselves with other nutritional needs and therefore do not usually have sufficient macronutrients and micronutrients. Model diets developed by nutritionists generally do not fully consider food costs and as a result are not low in cost. What all of this means is that it was necessary to develop a new approach to creating a model diet for estimating a living wage. We have developed two Excel model diet programs to help create a model diet for a living wage.

\subsection{Key Features of the Approach Used to Create a Living Wage Model Diet and Estimate its Cost}

Key features of the approach we developed for creating a model diet include: 
- WHO recommendations for calories, proteins, fats, carbohydrates and fruits and vegetables are used.

- We created an Excel calorie requirement program to calculate the number of calories required per person per day for a reference size family based on WHO (2004) recommendations.

- We created an Excel model diet program to develop an appropriate model diet for a living wage.

- The Excel model diet program uses a practical iterative process. First, a preliminary model diet is created based on a model diet from nutritionists, or a model diet used to estimate a poverty line, or food consumption reported in a household survey. This starting diet is, then, adjusted to ensure that WHO nutritional recommendations are met, the diet is consistent with local food preferences, and the diet is relatively low in cost for a nutritious diet by taking relative food prices into consideration.

- The model diet purposely includes a limited number of relatively inexpensive foods (around 20 foods) for simplicity. The cost of this model diet is then increased by a small percent to allow for the purchase of a greater variety of foods. This is in contrast to the 35-60 food items usually included in poverty line and other model diets. The advantage of our method is that it is simpler, yet accomplishes the same thing of ensuring variety.

- The Excel model diet program takes into account the difference between amount of food purchased and amount edible. This avoids a common mistake of other living wage estimates - which is to calculate the number of calories based on purchased weight of foods without deducting the weight of inedible parts such as skin of banana, shell of egg, and bone in meat.

- The Excel model diet program is flexible. It can be used to modify a model diet created by nutritionists to ensure that it is relatively low in cost, or to modify a model diet based on reported local food consumption so that it satisfies various nutritional standards.

The remainder of this chapter is divided into three parts. Part II indicates general characteristics of an appropriate low-cost nutritious model diet for estimating living wage. Part III discusses nutritional requirements in depth. Part IV is concerned with how to create an appropriate model diet. It describes three approaches typically used to develop model diets, as well as our new approach and provides an example. 


\section{PART II. PRINCIPLES OF MODEL DIET FOR ESTIMATING A LIVING WAGE}

Model diets created for estimating a living wage should ideally be nutritious, relatively low in cost, consistent with local food preferences, consistent with a country's development level, and expressed as far as possible in number of portions per week or per day so that it is easy to understand by the public. Each of these characteristics is discussed below:

\subsection{Characteristics of a Model Diet}

\subsubsection{Model diet should be nutritious}

The following guidance is used to ensure that the model diet created for a living wage study follows WHO recommendations on nutrition:

- Number of calories in the model diet needs to be sufficient according to WHO (2004) recommendations. We created an Excel calorie requirement program for this calculation.

- At least $10 \%$ of calories must come from proteins as recommended by WHO/FAO (2003). Also, in accordance with these recommendations, proteins need to come from a variety of sources including some 'higher quality' sources of proteins such as foods of animalorigin and legumes.

- Some dairy (which is rich in calcium and high quality protein) should be included in the diet, especially for children (FAO, 2014a).

- $15-30 \%$ of calories must come from fats as recommended by $\mathrm{WHO} /$ FAO (2003).

- $55-75 \%$ of calories must come from carbohydrates as recommended by WHO/FAO (2003).

- At least 300 grams $^{1}$ of vegetables and fruits per day (including legumes) must be included in the model diet to help provide micronutrients and minerals.

\subsubsection{Foods in a model diet should be consistent with local preferences}

A model diet should reflect local food preferences so that it is palatable to the local population. This means that the diet should include the types of foods preferred in the location. For example, the preferred cereal in a country might be rice, wheat, or maize; the preferred root and tuber might be potato or cassava; the preferred legume might be dhal, or beans; and the preferred meat might be chicken, pork, or beef. 


\subsubsection{Model diet should be relatively low in cost for a nutritious diet}

A model diet should include less expensive meats, cereals, fruits, vegetables, etc. in order to keep food costs down while maintaining nutrition. Section 4.9.3 discusses how lower cost food items to include in a model diet are chosen.

\subsubsection{Model diet should be consistent with development level of location}

Consumption of foods that are relatively expensive per calorie (e.g. meats, fruits, and vegetables) is known to increase with economic development and per capita income, because people have a preference for these foods when they can afford them. An increasing percentage of calories from proteins usually goes hand in hand with economic development. For this reason, quantities of more expensive foods should increase in a living wage model diet along with economic development.

\subsubsection{Model diet should be expressed as far as possible in numbers of servings so it is easy to understand}

Quantities of each food in a model diet should be stated, to the extent possible, in a way that is understandable to the public. This increases transparency and the ability to convey the type of basic life style that a living wage is able to support. For example, the model diet we used to estimate a living wage in the Dominican Republic included one roll of bread per day, one cup of milk per day for children, three eggs per week, six meat meals per week, three tablespoons of cooking oil per day, and seven teaspoons of sugar per day.

\section{PART III. NUTRITIONAL RECOMMENDATIONS USED TO CREATE A MODEL DIET FOR A LIVING WAGE}

As mentioned above, our Excel model diet program uses WHO/FAO recommendations on calories and nutrients to ensure that the model diet is nutritious. This section begins with a description of how calorie requirements are calculated and describes how to use the Excel calorie requirements program. Next, protein requirements are discussed in detail, because foods that are high in protein tend to be relatively expensive and therefore the amount of protein in a diet is an important determinant of its cost. Third, details are presented about the number of edible grams of each of the major food groups to include in the model diet, such as amounts of fruits and vegetables, milk and dairy, sugar, oils and fats. 


\subsection{How to Determine Calories Needed for a Family}

Since ensuring that a model diet has sufficient calories is essential, we created an Excel calorie requirement program to calculate the number of calories required per person per day for different family sizes.

Calculation of the number of calories in the model diet is based on WHO (2004) guidelines on the average number of calories people need per day. Calorie requirements are calculated separately for adults and children. The average number of calories required per person for a family depends on the reference family size. Equations to calculate the average number of calories per person needed (known as the Schofield equations) are based on:

- age

- sex

- body size

- physical activity level

\subsubsection{Calories needed for adults}

Adults require energy for: (1) basic bodily functions and (2) physical activity. Adults no longer require energy for growth.

\subsubsection{Calories needed for basic bodily functions (adults) BMR (basic} metabolic rate) is the number of calories needed for basic body functions essential for life, such as 'cell function and replacement; the synthesis, secretion and metabolism of enzymes and hormones . . .; maintenance of body temperature; the uninterrupted work of cardiac and respiratory muscles; and brain function' (WHO, 2004, p. 7). BMR is related to body size, age and sex, and it represents $45-70 \%$ of an adult's daily energy expenditure. For our living wage model diet, we use average values for males and females ages 30-60. The Schofield equations for males and females ages 30-60 are as follows (WHO, 2004):

1. BMR per day for males ages $30-60=873.1+11.472 \times \mathrm{kg}$

2. BMR per day for females ages $30-60=845.6+8.126 \times \mathrm{kg}$

WHO (2004) suggests using the weight that corresponds to the average attained adult height and a body mass index (BMI) ${ }^{2}$ of 21 as the basis for estimating calorie requirements rather than average body weight. Average attained height of a population is a stable indicator of nutritional needs, as it varies little during adulthood. We follow this recommendation. 
3.3.1.2 Calories needed for physical activity (adults) Calories needed for physical activity vary greatly from activity to activity. These differences are expressed by the physical activity ratio (PAR), which when multiplied by $\mathrm{BMR}$ indicates calories required for a particular activity. The PAR for sleep, for example, is 1, while the PAR for dressing and showering is 3.3, and the PAR for non-mechanized agricultural work is $4.1 .^{3}$ Since a person does a variety of activities during a day, in order to get an estimate of the overall physical activity ratio for a day, PAR values are weighted by the length of time of each activity and summed.

PAR for a typical day has been categorized into three overall physical activity levels (PAL) - namely light activity (sedentary), moderate activity, and vigorous activity with PAL values of 1.4-1.69, 1.7-1.99, and 2.0-2.4 respectively. For example, a light activity day might consist of 8 hours of sleep (PAR 1), 8 hours of office work (PAR 1.5), 2 hours of light leisure activities such as chatting or watching TV (PAR 1.4), and 1 hour each of personal care (PAR 2.3), eating (PAR 1.5), cooking (PAR 2.1), general housework (PAR 2.8), driving a car to and from work (PAR 2.0) and walking without a load (PAR 3.2). The weighted average of these activities during the day in this example is a PAL of 1.53, which is in the light activity range.

If 8 hours of office work (PAR 1.5) is replaced by 8 hours of nonmechanized agricultural work (PAR 4.1), 1 hour of general household work (PAR 2.8) by 1 hour collecting water/wood (PAR 4.4), and 1 hour of driving a car to and from work (PAR 2.0) by 1 hour of non-mechanized domestic chores (PAR 2.3), the overall PAL is 2.25, which is in the vigorous activity range.

The average number of calories required at each activity level equals PAL $\times$ BMR. We use the mid-point of each PAL range to estimate calorie needs for the living wage model diet as this is customary (Table 3.1).

Table 3.1 PAL multipliers for sedentary, moderate, and vigorous life styles

\begin{tabular}{lcc}
\hline Physical activity level (PAL) & Range of PAL values & Mid-point of range \\
\hline Light & $1.41-1.69$ & 1.55 \\
Moderate & $1.70-1.99$ & 1.85 \\
Vigorous & $2.00-2.40$ & 2.20 \\
\hline
\end{tabular}

Source: WHO (2004). 


\subsubsection{Calories needed for children and adolescents}

Children and adolescents require energy for growth as well as for basic body functions and physical activity. We use values from WHO (2004) ${ }^{4}$ to estimate calorie needs of children for our model diet. These values are based on Schofield equations and represent energy requirements for a reference population with moderate activity level for a broad spectrum of countries. The average number of calories required per day for children ages $0-17$ with moderate activity level is $1892 .{ }^{5}$ If children engage in vigorous activities such as walking or biking long distances to school and doing several hours of energy-demanding chores every day, or practice energy-demanding sports for several hours a day, the average number of calories required per day per child would be 2221, whereas if children have a sedentary life style (e.g. use motorized vehicles to get to school, and spend almost all of their leisure time in sedentary activities such as reading, watching television, or playing with very little body displacement) and do not engage in any sports, average daily calorie requirements would be 1663 .

It is customary to assume that children have moderate activity levels, since they should spend much of their time in school. Calorie requirements for light activity level or a vigorous activity level can be used when there is a good reason to believe that these represent local conditions.

\subsubsection{Calories needed for a reference size family}

We recommend using the following assumptions for physical activity levels to calculate calorie needs:

- Vigorous activity level for adults engaging in non-mechanized farm work

- Moderate activity level for other adults

- Moderate activity level for children

These are typical assumptions but are relatively conservative assumptions for rural areas where physical activity is generally more intense than in urban areas. In rural areas, for example, all adults might have vigorous activity levels. Some judgment is needed here. In the rural area of Malawi, for example, where there is no electricity and water and firewood for cooking have to be collected by family members, all adults have vigorous activity. In contrast, in rural Dominican Republic where there is generally piped water and electricity and cooking is generally done with LPG gas, we considered that only one adult (the worker on a farm/plantation) had vigorous activity. 


\subsubsection{Additional calories needed during pregnancy and lactation}

3.3.4.1 Pregnancy According to WHO (Clugston, n.d.) a woman needs on average 285 additional calories per day during pregnancy. (More calories are needed in the last trimester, and fewer additional calories are needed during the first trimester.) While it is extremely important that pregnant women have additional calories, pregnancy does not add many extra calories on average per person in the family, since additional calories are only needed for nine months per full-term pregnancy, only for years in which the mother is pregnant, and only for one family member. In populations where women have two children on average, the additional 285 calories per day needed for each pregnancy when averaged over all childbearing years implies an additional 12 extra calories per day for the woman, and so only three additional calories per day per family member for a family of four. Even in a country with extremely high fertility, additional calories required for pregnancy are small when averaged over all years for the entire family. The Excel calorie requirements program makes a small addition for calorie needs during pregnancy.

3.3.4.2 Lactation Our Excel calorie requirement program does not adjust average calorie requirements for lactation partly because additional calories needed for lactation vary enormously with feeding practices (such as length and exclusivity of breastfeeding) which vary widely from country to country (WHO, 2004). In addition, production of human milk has been estimated to be $80-85 \%$ efficient (Butte and King, 2002), so that most of the calories needed to produce human milk ultimately go to the breastfed child. While adding a small number of additional calories per person for lactation in some high fertility countries may be reasonable, the adjustment would be small when averaged over the entire family and over many years. ${ }^{6}$

\subsubsection{National databases for calorie requirements}

Some countries have national nutritional standards based on international standards and local conditions. For example, the Government of India, National Institute of Nutrition (2010) has nutritional standards for India. They estimated their own PARs (physical activity ratios) and PALs (physical activity levels) based on typical activities and life styles in India. ${ }^{7}$ They also have standards for proteins and other micronutrients based on foods found in the Indian diet. Similarly, the Government of Vietnam, National Institute of Nutrition (2014) have their own equations for calorie requirements and physical activity levels. Such national standards could be used when they are available and based on high quality research. 


\subsubsection{Excel program for calculating calories needed}

We created an Excel program to calculate the number of calories needed by a reference size family. The Excel calorie requirement program has four worksheets. It is available on the Edward Elgar website.

\subsubsection{Calorie requirements worksheet 1 The first worksheet entitled} '1. Adults' calculates calorie requirements for adult males and females with sedentary, moderate and vigorous activity levels. To use this worksheet, input the average attained height of adult males and females in cells E14 and E15. The worksheet automatically calculates the healthy weight of the population using a BMI of 21 (in cells G14 and G15). ${ }^{8}$ The program also calculates the calorie requirements based on this weight with sedentary, moderate and vigorous activity levels (cells F30 through $\mathrm{H} 40)$.

The attained height of adult males and females can often be found from nutritional studies or from a table in Wikipedia (2014) called 'average height around the world.' This table not only lists heights, but importantly also provides references. The Demographic and Health Survey (DHS) is another source of information on attained height - but only for the height of women. If DHS is used for adult women, a reasonable assumption for adult males would be to multiply women's height by $1.08 .{ }^{9}$ Note that if it is not possible to find average adult height, weight can be used as the input into the spreadsheet (although it is preferable to use height).

\subsubsection{Calorie requirements worksheet 2 The second worksheet entitled}

'2. Calories per family member' calculates the average number of calories per person for the reference family size. For this worksheet, it is necessary to input the reference family size plus assumptions about activity levels. A small addition to this is added for pregnancy based on the number of children in the reference size family.

\subsubsection{Calorie requirements worksheet 3 The third worksheet entitled} '3. Calories per child' consists of tables with calorie needs for children and for infants. Calorie needs for children and infants are assumed to be the same worldwide. This worksheet is included for reference purposes only. It is used in Worksheet 4 as a basis for determining the replacement cost of meals provided at school or work. No input is required for Worksheet 3 .

\subsubsection{Calorie requirements worksheet 4 The fourth worksheet entitled}

'4. Estimated cost of meals' calculates the replacement cost of meals eaten away from home by children and adults. It is used to calculate how much money is saved when children are provided free meals in school or adults 
are provided meals by their employer. Worksheet 4 uses information from Worksheets 1, 2, and 3 .

VALUE OF MEALS PREPARED AT HOME FOR ADULTS AND REPLACEMENT COST OF MEALS IN THE WORKPLACE Assumptions about the proportion of daily calories consumed in each meal - breakfast, lunch and dinner - should be entered in cells F13-F15 of Worksheet 4. Check to see that the sum of these proportions is 1 (cell F16). Then enter cost of the model diet per person per day in cell F21. Worksheet 4 calculates the replacement cost of breakfast, lunch and dinner for adults provided with meals at work based on the cost of the model diet and the worker's activity level.

VALUE OF CHILDREN'S MEALS PREPARED AT HOME AND REPLACEMENT VALUE OF FREE LUNCH AT SCHOOL When children eat free meals at school, the cost of food for the family should be reduced by the amount it would have cost to prepare the school meal at home. This can be calculated from the Excel calorie requirements program.

The cost of lunch for children of different ages is calculated in cells E38 to E55. The following equation can be used to calculate the average replacement value of a free lunch provided at school. The equation takes into account that the lunch is provided only for children of certain ages, and only on school days:

Replacement value of free lunch provided in school $=(\#$ years of school during which free lunch is provided $\div 18$ years as a child $) \times($ number of school days in year $\div 365) \times($ average value of free lunch for relevant age groups from Excel program)

The replacement value of free lunches at school should be deducted from the cost of the living wage model diet since free school lunches reduce the need for families to provide lunch for their children.

\subsection{Proteins}

Food costs are sensitive to the amount and quality of proteins in a diet, because high quality proteins are relatively expensive per calorie (see Anker, 2006 and 2006a). Healthy diets should have at least $10-15 \%$ of calories from proteins according to WHO/FAO (2003) and proteins should come from a variety of sources with a substantial proportion of high quality proteins such as from meat, fish, chicken, egg, and dairy (WHO/FAO/UNU, 2007). We suggest that all model diets contain some high quality proteins daily, and this amount should increase with economic development. 


\subsubsection{What are proteins and how many are needed?}

Proteins are large complex molecules made up of 20 different smaller molecules called amino acids combined in long chains. Amino acids are required to maintain good health, especially to build, maintain and replace body tissues and organs. Eight amino acids are considered to be 'essential amino acids' (that adults cannot synthesize themselves and so must be obtained from food). There are 10 essential amino acids for children.

Determining how much protein is required for health is difficult, because proteins differ in their amino acid composition and in how easily they can be digested (Millward, 2013). Consequently, recommendations on required amounts and types of proteins are complex and controversial. Nonetheless, WHO/FAO (2003) and WHO/FAO/UNU (2007) recommend that a minimum of $10 \%$ of calories should come from proteins. CDC (2013a) also suggests that at least $10 \%$ of daily calories come from proteins. We follow this recommendation. We suggest that around $10-11 \%$ of calories should come from proteins for low income countries, with this percentage rising with development level and per capita income such as to $11-12 \%$ for lower middle income countries, $12-14 \%$ for upper middle income countries, and $15+\%$ for high income countries.

Some of the proteins in the living wage model diet should be high quality proteins in keeping with the most recent revision of WHO/FAO/UNU (2007) guidelines on protein and amino acid requirements. This is especially critical in countries with considerable malnutrition. A recent review of protein quality and malnutrition in Africa highlighted the need for adequate amounts of protein and for high quality protein - 'the amount of protein consumed is insufficient in comparison with requirements ... The low intake of good-quality protein remains a threat to livelihoods' (Schoenfeldt and Hall, 2012, S69). Since high quality proteins, especially animal-based foods, are relatively expensive per calorie, large amounts would make the model diet too expensive, but at least 20 grams of high quality proteins should usually be included in model diets.

\subsection{Suggested Number of Grams to Include in Living Wage Model Diet for Each Food Group}

WHO and FAO recommend amounts of foods to consume daily from each food group to ensure sufficient macronutrients and micronutrients.

\subsubsection{Fruits and vegetables}

Fruits and vegetables are important for good nutrition as they contain many micronutrients not found elsewhere. According to WHO (n.d.), benefit of fruits and vegetables cannot be ascribed to a single or mix of 
nutrients and bioactive substances. Therefore, this category was included rather than the nutrients themselves.' Our model diet follows the same strategy - of not listing every micronutrient and bioactive substance of importance, but assuming that eating sufficient amounts of a variety of fruits and vegetables will provide necessary micronutrients.

WHO/FAO (2003) recommends that people eat at least 400 grams of fruits and vegetables per person per day - not including roots and tubers (such as potatoes and cassava) but including legumes such as beans and pulses. This is equivalent to at least five servings of fruits and vegetables per day (using a standard serving size of approximately 80 grams).

However, a low percentage of people in the world actually consume $400+$ grams of fruits and vegetables per day. According to WHO (n.d.) 'only a small and negligible minority of the world's population consumes the generally recommended high average intake of fruits and vegetables.' This is especially true for developing countries. A review of fruit and vegetable consumption in 10 Sub-Saharan African countries (Ruel et al., 2005) indicated that average consumption of fruits and vegetables was well below 200 grams per person in all 10 countries, with fruit and vegetable consumption lowest in the poorest quintile in each country. An analysis of the 2002-2003 World Health Survey from 52 mainly low and middle income countries (Hall et al., 2009) indicated that $78 \%$ of respondents 'consumed less than the minimum recommended 5 servings of fruits and vegetables.' Low consumption of fruits and vegetables in lower income countries is not surprising because they are expensive per calorie (e.g. studies for Rwanda and Cambodia cited in Ruel et al. (2005) found that tomatoes were 12 times more expensive per calorie than starches in Rwanda; and vegetables in Cambodia were 10 to 40 times more expensive per calorie than rice).

In view of the fact that the WHO recommendation is not reached by even close to a majority of people in even high income countries, ${ }^{10}$ we feel that it would be both unrealistic and unnecessary to include 400 grams per day of fruits, vegetables, and legumes in a living wage model diet. Instead, we include a minimum of 300 grams of fruits, vegetables, and legumes in living wage model diets for low income countries, and increase this by 25 grams with each development level (low income to lower middle income, lower middle income to upper middle income, and upper middle income to high income income). The lower limit of 300 grams is similar to the approximately 3-5 portions of vegetables and fruits per day recommended in the University of Stellenbosch model diet for South Africa (NICUS, 2007), and not very different from actual consumption levels of fruits and vegetables in high income countries. Note that $2-4$ vegetables should be included in a living wage model diet with at least one green leafy vegetable, 
as well as 1-2 fruits and 1-2 legumes in order to ensure a range of micronutrients (with additional variety of fruits and vegetables allowed for by funds for additional variety that are added to the cost of the model diet).

\subsubsection{Milk and dairy}

Living wage model diets should generally include at least 1 cup of milk per day for children and some milk for adults to add to coffee and tea, such as quarter of a cup, or possibly some yogurt or cheese. This recommendation is far from a hard and fast rule and some judgment is required especially in areas where people do not drink much milk out of choice.

Dairy is generally an important component of a diet. According to FAO (2014a), milk is 'a major source of dietary energy, high-quality protein and fat. . . Bioavailability of some nutrients in milk, for example calcium, is high compared with that in other foods in the diet.' The consumption of milk and dairy products is particularly important for calcium. 'The mineral profiles in milk and bones have much in common. With the exception of small fish that are eaten whole, including the bones, few foods naturally contain as much calcium as milk' (Muehlhoff et al., 2013, p. 125).

Despite the recognized need for milk, 'there are no global recommendations for milk or dairy consumption' (FAO, 2014a). Not surprisingly, countries vary widely in their recommendations for milk and dairy. A recent FAO review of national guidelines on milk and dairy consumption for 42 countries, including 14 developing countries, found that national recommendations differed widely (Muehlhoff et al., 2013). Of the 14 developing countries in this study, 11 recommended at least one and sometimes two cups of milk or dairy equivalent per day for both adults and children (exceptions being Oman and El Salvador, which recommended around half a cup of milk per day, and Guatemala, which recommended milk at least twice a week). It is worth noting that India (which has many vegetarians) and Chile among developing countries recommended the most milk or dairy (at least three servings per day). Most, but not all, developed countries recommended at least two servings of milk or dairy per day for adults and children.

There are also wide differences between countries in the consumption of dairy. The proportion of calories derived from dairy products in developing countries ranges from slightly less than 2\% in East and South-East Asia and 3\% in Sub-Saharan Africa to around 7\% in South Asia, Latin America and the Caribbean (Muehlhoff et al., 2013). Part of the reason for the low percentage in East and South-East Asia, may be widespread lactose intolerance among adults.

In light of the above, it is difficult to be dogmatic about the need to include large amounts of milk in model diets. The suggested minimum 
amount of milk for a living wage model diet stated above of one cup for children and a quarter of a cup for adults is on the low side relative to recommendations of nutritionists and national guidelines. Note that the amount of milk included in a living wage model diet sometimes needs to be limited because of its cost. The cost of milk in a model diet should not generally exceed somewhere around $10-15 \%$ of food expenditure except in countries such as India with many vegetarians who do not consume meats, fish, and egg.

\subsubsection{Meats, fish and eggs}

Meats, fish and eggs are relatively expensive per calorie. Despite this, they are included in model diets in part because they are important sources of high quality proteins, and in part because there is a strong preference for them in most countries. The quantity of meats, fish and eggs in living wage model diets depends on level of development and local preferences. The distribution of quantities between meats, milk, fish and eggs should depend to a significant extent on their relative prices. A living wage model diet needs to balance local preferences and relative prices to achieve a healthy but relatively inexpensive diet. For example, in Malawi, small dried fish were an important part of the local diet, and they were less expensive per protein and per calorie than either meat or chicken. Therefore, in Malawi, small dried fish was included in our model diet, but meat and chicken were not. In Kenya, fish was not included in our model diet because meat was preferred by most Kenyans, and was less expensive.

\subsubsection{Sugar}

Living wage model diets should generally include at most 30 grams of sugar per day (equivalent to around six to seven teaspoons of sugar per person per day), and less in countries with little sugar consumption. This recommendation is based on WHO (2015, p. 4):

WHO recommends reducing the intake of free sugars to less than $10 \%$ of total energy intake ... and suggests a further reduction of the intake of free sugars to below $5 \%$. . . For countries with a low intake of free sugars, levels should not be increased. Higher intakes of free sugars threaten the nutrient quality of diets by providing significant energy without specific nutrients.

Thirty grams of sugar a day is approximately 5\% of energy intake in a 2400 calorie diet. This amount can be increased somewhat in locations where it would not be palatable to have only 30 grams of sugar per person per day. 


\subsubsection{Oils and fats}

WHO recommends that $15-30 \%$ of calories should come from fats. Our living wage model diet typically includes 30-34 grams of oil per person per day (approximately equivalent to two tablespoons). Thirty grams of oil contains approximately 265 calories and 34 grams contains approximately 300 calories, which represent around $12-14 \%$ of calories for a diet with 2200 calories per day. Note that other items in the diet, such as animal products, also contain fats.

\subsubsection{Roots and tubers and starchy plantains}

The quantity of roots and tubers consumed varies greatly from country to country. For this reason, we suggest relying mainly on national data on local food consumption as a guide to determining the amount of roots and tubers to include in a living wage model diet. We also suggest relying on data on local food consumption to determine the amount of starchy plantains in a model diet. Starchy plantains should only be included in model diets in countries in which they are important. Although starchy plantains are a staple food in some countries, they are so unimportant in many other countries that they should not be included in the living wage model diet for many countries.

\subsubsection{Cereals}

Cereals are the most important source of calories in diets around the world. Cereals come in prepared forms (e.g., bread and noodles) and unprepared forms (e.g., rice and wheat flour). From one to four different cereals should be included in living wage model diets depending on consumption habits in the area. The amount of bread in a model diet should be set in terms of number of slices of bread or number of rolls. Note that in our Excel model diet program, the number of grams of unprepared cereals is determined after the number of calories from all the other foods has been calculated, to ensure that the model diet provides exactly the required number of calories.

\subsubsection{Beans, soy, pulses, legumes and nuts}

Nutritionists typically recommend eating legumes or soy often, because they are a good source of protein and other nutrients. However, there is high variation across countries in the extent to which diets include legumes and soy. Living wage model diets should generally contain between 28 and 56 grams (one to two servings) of beans, soy, pulses, legumes or nuts in light of their nutritional value (especially proteins) with number of grams dependent on local preferences. An upper limit is needed to keep a model diet palatable. 


\subsubsection{Coffee and tea}

Coffee and tea are drunk around the world. Living wage model diets should include one of these depending on local preferences. The amount should be determined using an assumption on the number of cups for adults per day. Soft drinks should not be included in a living wage model diet.

\section{PART IV. CREATING A LIVING WAGE MODEL DIET}

Part IV describes how a model diet for estimating a living wage should be developed. It begins by discussing three typical approaches for developing model diets. It goes on to describe the approach used in our living wage methodology and explains why this approach is used and its advantages over the other approaches. How to create a living wage model diet, and how to use the model diet Excel program are explained.

\subsection{Typical Approaches Used to Create Model Diets}

This section describes three typical approaches that have been used to create a model diet. One approach relies on recommendations of nutritionists who are interested in advising the public on healthy eating. A second approach relies on actual food consumption as observed on household expenditure surveys. This approach is often used to estimate poverty lines. A third hybrid approach relies on mathematical optimization processes using information on nutritional requirements, actual food consumption, and relative food prices. This approach is used by more sophisticated government departments and universities.

\subsubsection{Typical approach 1: Recommendation of nutritionists}

One typical approach has nutritionists creating a model diet that meets minimum nutritional standards and is consistent with national food preferences. Government ministries, nutrition institutes, and universities often create this type of model diet to provide advice and information to the public on healthy eating. These model diets are generally based on $\mathrm{WHO} /$ FAO recommendations.

The major advantage of this type of model diet for estimating a living wage is that the diet is nutritious. Other advantages are that such diets usually exclude foods like cookies, cakes, soft drinks, and alcohol that are not necessary for health, and that they almost always take into consideration national food preferences. Their main disadvantage is that they do not generally give very much consideration to food costs. Their main purpose is to inform the public about healthy eating. As a result, model diets 
created by nutritionists tend to be more expensive than we feel is warranted for estimating a living wage.

In summary, while model diets prepared by nutritionists are very useful to help to set a model diet for a living wage, they should not be used for estimating a living wage without adjustment because they tend to be unnecessarily expensive for a living wage. They are, however, a useful basis for starting to construct an appropriate diet for estimating a living wage.

\subsubsection{Typical approach 2: Reported food consumption}

A second common approach determines a model diet based on reported food consumption from a household expenditure survey. Such model diets are commonly used by the World Bank and governments to estimate food costs for poverty lines (Ravaillon, 1998). Based on household survey data, the average number of calories per person per day is calculated for each household. The household income decile or quintile where the required number of calories per person is achieved is identified - and the reported food consumption of this household income decile or quintile becomes the model diet used to estimate a poverty line. ${ }^{11}$ There are usually around 35-60 food items included in such model diets because only common food items are included.

This approach has several advantages for estimating a living wage. It ensures that the model diet has a sufficient number of calories. It ensures that the model diet is consistent with local food preferences and the qualities and quantities of foods that people purchase. This approach also has several disadvantages. It does not ensure that the model diet is nutritious beyond having a sufficient number of calories. As it happens, the poorer a country the more likely it is that a model diet based exclusively on reported food consumption will be unacceptable nutritionally and/or culturally. This is because many poor people in poor countries do not have enough income to eat well. Another disadvantage is that reported food consumption data are often problematic because of numerous technical difficulties in collecting such data from households. In Vietnam, for example, 31\% of food expenditure was for foods with unknown numbers of calories such as meals eaten away from home and 'other vegetables' (Vietnam National Wage Council, 2014). It is difficult to understand from these data exactly what foods and how many calories households in Vietnam actually consume. A further complication is that many countries include alcohol, tobacco, narcotics, and food eaten away from home in restaurants and street markets as part of food expenditures (Anker, 2011a).

In summary, while model diets based on actual food consumption have important advantages, they should not be used to estimate a living wage 
without adjustments. They can, however, provide a useful basis to start to construct an appropriate model diet for estimating a living wage.

\subsubsection{Typical approach 3: Mathematical optimization model}

A third approach uses a mathematical optimization model. It, in essence, melds the two approaches described above while also taking food prices into consideration. A model diet is set using a mathematical optimization model that takes into consideration nutritional standards (e.g. calories, macronutrients, micronutrients), food habits and preferences (e.g. actual food consumption), and food prices and costs. The food baskets ${ }^{12}$ developed by the United States Department of Agriculture (USDA) provide good examples of this approach ${ }^{13}$ - although it is worth noting that USDA (2007) uses common sense when necessary, because blind use of its mathematical optimization model often leads to nonsensical results. ${ }^{14,15}$

There are several advantages to this approach. It takes into account nutritional requirements, food preferences, and food prices in such a way as to minimize costs while maintaining nutrition and food preferences. The main disadvantages of this approach are its complexity, high skill level required to use it, and need for considerable judgment to ensure reasonable results. These disadvantages mean that this approach is not practical to use on a widespread basis.

\subsection{Our Approach to Creating a Living Wage Model Diet: A Practical Optimization Process}

We use a simplified version of the third approach described above to create a living wage model diet. For this purpose we developed an Excel model diet program that uses an iterative process. First, initial quantities and specific foods in the diet are specified based on actual food consumption or on nutritional guidelines for the location or country. Then adjustments are made to this initial diet to ensure nutritional quality, acceptability to local workers, and relatively low-cost.

Section 3.7.1 explains the general structure of our living wage model diet and how to select specific foods from each major food group. Section 3.7.2 discusses cost of salt, spices, and condiments. Section 3.7.3 discusses the need for a varied diet and its extra cost, while Section 3.7.4 discusses the cost of food spoilage and wastage. Inedible portions of foods and the nutritional content of foods are discussed in Sections 3.7.5 and 3.7.6. The Living Wage Excel model diet program is discussed in Section 3.8. 


\subsubsection{General structure of a living wage model diet: 11 food groups}

A living wage model diet should generally include 11 food groups with around 20 food items. Table 3.2 indicates typical food groups and typical food items included in a living wage model diet. There are two groups of cereals, unprepared cereals or grains (such as rice, wheat, maize, etc.) and prepared cereals (such as bread and noodles). Prepared cereals are optional and should only be included when they are an integral part of the local diet. Roots and tubers and starchy fruits and vegetables are also divided into two groups. Starchy fruits and vegetables such as plantains should only be included in a model diet when they are an important part of the diet in a location. Vegetables are also divided into two groups, green leafy vegetables and other vegetables. This is because diets should contain a variety of vegetables. The cost of a model diet is then increased by a small percentage to allow for salt, spices and condiments; minimal spoilage; and some additional variety.

\subsubsection{Salt, spices, sauces and condiments}

Salt, spices, sauces and condiments are required for food to be palatable. For simplicity, living wage model diets increase food costs by a small percentage to allow for salt, spices, and condiments rather than specifying many different items in the model diet. An appropriate percentage to use depends on the complexity of local cuisine. ${ }^{16} \mathrm{~A}$ useful source for determining what percentage to add to food costs for salt, spices, sauces and condiments are household expenditure survey data or CPI expenditure weights. In the absence of national data on household expenditure for salt, spices and condiments, 1-3\% should be used (although this percentage can be higher as it was above 5\% in study areas in Bangladesh, India and Sri Lanka according to household income and expenditure surveys).

\subsubsection{Importance of variety in a diet}

Variety is important for a nutritious diet. No one can be expected to eat exactly the same foods every day as this would not be palatable - nor would this be nutritious as variety is important to ensure a range of micronutrients, macronutrients, and minerals. Model diets typically account for this by including 35-60 food items. For practical reasons, a living wage model diet includes fewer foods (usually around 20 food items) - and then increases the total cost of the model diet by a certain percentage to allow for additional variety. This is a much simpler way to accomplish the same goal of providing for needed variety.

We recommend adding between $10 \%$ and $15 \%$ to the cost of a living wage model diet for variety. What percentage to use should depend on the number of food items included in a living wage diet (the more food items included the lower the additional percentage needed for variety), extent 
Table 3.2 Typical food groups, examples of specific foods, and amounts typically included in a living wage model diet

$\begin{array}{llll}\begin{array}{l}\text { Food groups } \\ \text { included in }\end{array} & \begin{array}{l}\text { Examples of } \\ \text { specific food }\end{array} & \text { Amount (number of } & \text { Comments } \\ \text { model diet } & \text { items } & \end{array}$

\begin{tabular}{|c|c|c|c|}
\hline $\begin{array}{l}\text { 1A. Cereals } \\
\text { and } \\
\text { grains }\end{array}$ & $\begin{array}{l}\text { Rice } \\
\text { Wheat } \\
\text { Maize }\end{array}$ & $\begin{array}{l}\text { Number of grams } \\
\text { of most important } \\
\text { cereal set by Excel } \\
\text { program. }\end{array}$ & $\begin{array}{l}\text { Include } 1-3 \text { common } \\
\text { cereals with the most } \\
\text { important cereal in the } \\
\text { first row. Use minimum } \\
\text { acceptable quality. }\end{array}$ \\
\hline $\begin{array}{l}\text { 1B. Prepared } \\
\text { cereals } \\
\text { (optional) }\end{array}$ & $\begin{array}{l}\text { Bread } \\
\text { Pasta }\end{array}$ & $\begin{array}{l}\text { Base amount on } \\
\text { number of grams in } \\
\text { typical unit (e.g. in } \\
\text { slice or roll of bread). }\end{array}$ & $\begin{array}{l}\text { Include when common. } \\
\text { More expensive } \\
\text { per calorie than } \\
\text { unprepared cereals. } \\
\text { Often excluded in } \\
\text { low income countries. } \\
\text { Exclude cakes. }\end{array}$ \\
\hline $\begin{array}{l}\text { 2A. Roots } \\
\text { and } \\
\text { tubers }\end{array}$ & $\begin{array}{l}\text { Potato } \\
\text { Cassava } \\
\text { Sweet potato }\end{array}$ & $\begin{array}{l}\text { Base amount } \\
\text { on typical } \\
\text { consumption in } \\
\text { country/location. }\end{array}$ & $\begin{array}{l}\text { Include } 2 \text { items when one } \\
\text { type is not dominant. }\end{array}$ \\
\hline $\begin{array}{l}\text { 2B. Starchy } \\
\text { fruits and } \\
\text { vegetables } \\
\text { (optional) }\end{array}$ & $\begin{array}{l}\text { Plantains } \\
\text { Green banana }\end{array}$ & $\begin{array}{l}\text { Base amount on } \\
\text { typical consumption } \\
\text { in country/location. }\end{array}$ & $\begin{array}{l}\text { Include only when } \\
\text { important part of local } \\
\text { diet. Include } 1-2 \text { items. }\end{array}$ \\
\hline $\begin{array}{l}\text { 3. Legumes } \\
\text { and nuts }\end{array}$ & $\begin{array}{l}\text { Beans } \\
\text { Pulses } \\
\text { Peas } \\
\text { Lentils } \\
\text { Soy and tofu } \\
\text { Nuts }\end{array}$ & $\begin{array}{l}\text { Base amount on } \\
\text { typical consumption } \\
\text { in country/location } \\
\text { and need for low-cost } \\
\text { high quality proteins. }\end{array}$ & $\begin{array}{c}\text { Include 1-2 lower cost } \\
\text { acceptable varieties. }\end{array}$ \\
\hline 4. Dairy & $\begin{array}{l}\text { Milk } \\
\text { Cheese } \\
\text { Yoghurt }\end{array}$ & $\begin{array}{l}\text { Usually at least } 1 \text { cup } \\
\text { of milk for children } \\
\text { and } 1 / 4+\text { cup for } \\
\text { adults. }\end{array}$ & $\begin{array}{l}\text { Convert powdered milk } \\
\text { into equivalent cups of } \\
\text { liquid milk. Amount } \\
\text { of dairy included in } \\
\text { diet increases with } \\
\text { development. }\end{array}$ \\
\hline 5. Eggs & $\begin{array}{l}\text { Chicken egg } \\
\text { Duck egg }\end{array}$ & $\begin{array}{l}\text { Base amount on } \\
\text { number of grams in } \\
\text { medium size eggs. }\end{array}$ & $\begin{array}{l}\text { Use most common and } \\
\text { least expensive egg. } \\
\text { Usually chicken egg. } \\
\text { Amount increases } \\
\text { with development. } \\
\text { When weight is not } \\
\text { marked on }\end{array}$ \\
\hline
\end{tabular}


Table 3.2 (continued)

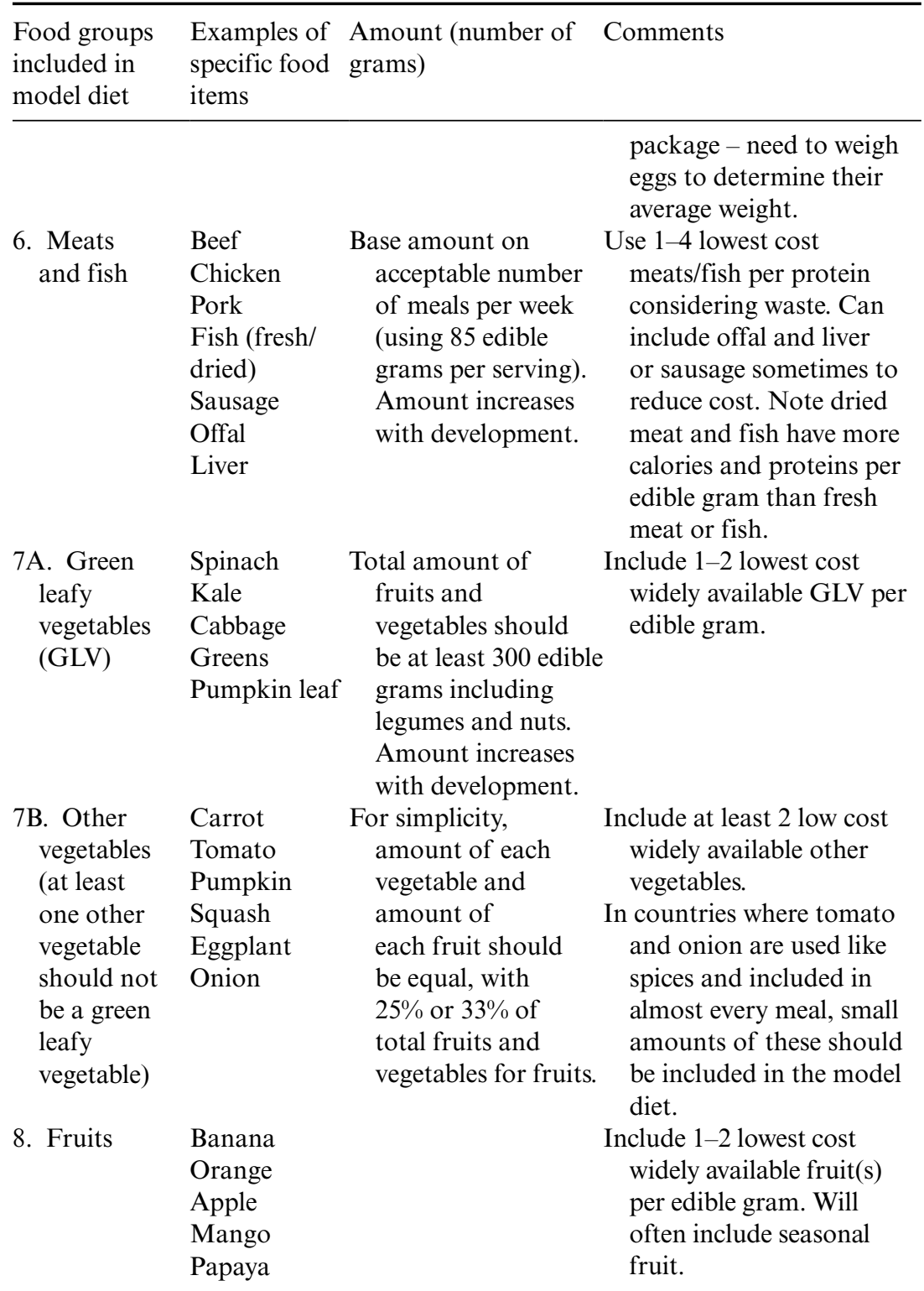


Table 3.2 (continued)

\begin{tabular}{|c|c|c|c|}
\hline $\begin{array}{l}\text { Food groups } \\
\text { included in } \\
\text { model diet }\end{array}$ & $\begin{array}{l}\text { Examples of } \\
\text { specific food } \\
\text { items }\end{array}$ & $\begin{array}{l}\text { Amount (number of } \\
\text { grams) }\end{array}$ & Comments \\
\hline $\begin{array}{l}\text { 9. Oils and } \\
\text { fats }\end{array}$ & $\begin{array}{l}\text { Sunflower oil } \\
\text { Corn oil } \\
\text { Animal fat }\end{array}$ & $\begin{array}{l}30-34 \text { grams ( } 2-2.5 \\
\text { tablespoons) usually. }\end{array}$ & $\begin{array}{l}\text { Include lowest cost } \\
\text { acceptable oil/fat per } \\
\text { liter. }\end{array}$ \\
\hline 10. Sugar & $\begin{array}{l}\text { Brown sugar } \\
\text { White sugar }\end{array}$ & $\begin{array}{l}24-30 \text { grams (6-7 } \\
\text { teaspoons) usually. }\end{array}$ & $\begin{array}{l}\text { Include lower cost } \\
\text { sugar per kilo. Exclude } \\
\text { confectionaries. }\end{array}$ \\
\hline $\begin{array}{l}\text { 11. Non- } \\
\text { alcoholic } \\
\text { beverages }\end{array}$ & $\begin{array}{l}\text { Tea } \\
\text { Coffee }\end{array}$ & $\begin{array}{l}\text { 2-3 cups per adult of } \\
\text { either coffee or tea } \\
\text { (usually } 2 \text { grams per } \\
\text { cup of tea, } 7 \text { grams } \\
\text { per cup of coffee). }\end{array}$ & $\begin{array}{l}\text { Include lower cost } \\
\text { acceptable quality } \\
\text { coffee or tea. Exclude } \\
\text { soft drinks. } \\
\text { Exclude alcohol and } \\
\text { wine. }\end{array}$ \\
\hline $\begin{array}{l}\text { 12. Other } \\
\text { (Optional) }\end{array}$ & $\begin{array}{l}\text { Coconut } \\
\text { Fish sauce }\end{array}$ & & $\begin{array}{l}\text { Include in countries } \\
\text { where a food is used in } \\
\text { almost all meals and is } \\
\text { not accounted for in } \\
\text { the above food groups } \\
\text { (e.g. coconut in Sri } \\
\text { Lanka and fish sauce in } \\
\text { Vietnam). }\end{array}$ \\
\hline $\begin{array}{l}\text { (Additional to } \\
\text { model diet) } \\
\text { Spices, salt, } \\
\text { sauces and } \\
\text { condiments }\end{array}$ & $\begin{array}{l}\text { Salt } \\
\text { Spices } \\
\text { Sauces } \\
\text { Condiments } \\
\text { Soup cubes }\end{array}$ & $\begin{array}{l}\% \text { of cost of model } \\
\text { diet. Base on typical } \\
\% \text { of household } \\
\text { food expenditure } \\
\text { according to } \\
\text { household } \\
\text { expenditure data. }\end{array}$ & $\begin{array}{l}\text { Typically } 1-3 \% \text { of all food } \\
\text { costs. } \\
\text { Exclude snacks. }\end{array}$ \\
\hline
\end{tabular}

to which one or two food items is dominant in food groups, and development level as additional variety becomes increasingly expected with greater economic development (e.g. United States Thrifty Food Plan includes 7 cereals, 10 dairy, 19 vegetables, 11 fruits, 4 oils, and 4 sugars). 


\subsubsection{Food wastage and spoilage}

Even under the best of circumstances, some food is wasted. People are not perfect housekeepers, and there is always some spoilage and food loss due to mold, insects, rodents, etc. In addition, some food is discarded or burnt. Spoilage is particularly important in poorer environments where there is restricted food storage capacity and lack of refrigeration, while discarded food is particularly important in more developed countries. We recommend adding 3-5\% to the cost of a model diet for wastage and spoilage. This percentage increases with development. This assumption is very conservative. In the United States, for example, the government Thrifty Food Plan recommended for low income persons assumes 10\% waste and the liberal Food Plan assumes $20 \%$ waste (USDA, 2007).

\subsubsection{Inedible parts of food}

Parts of many foods are not consumed because they are inedible. For example, people do not eat the skin of a banana, or the pit of a mango, or the shell of an egg. Since model diets are expressed in edible grams and food prices often include inedible parts, it is necessary to know the proportion of each food that is edible. Values for proportion inedible for a wide variety of foods are available from a USDA NAL nutrient online database (see Appendix 3.1).

3.7.5.1 Country-specific values for proportion inedible It often makes sense to adjust USDA NAL values for percentage inedible to be more realistic for a country or to use country-specific databases. There are several reasons why this is often a good idea, especially for vegetables. The FAO/ INFOODS (International Network of Food Data Systems) website lists country- and region-specific food composition databases.

1. Not all foods are included in the USDA NAL database. It is not unusual to come across foods in developing countries that are not included in the USDA NAL database. For example, in Malawi many varieties of fish are found only in Lake Malawi. There are different varieties of mangos around the world, some with large pits and some with small pits, and different varieties of oranges, tangerines, and bananas with thicker or thinner skins.

2. Foods are often prepared for sale differently in other countries than in the United States and this affects the proportion inedible. For example in Vietnam, vegetables sold in local markets include roots and stems (that are usually cut off before sale in the United States). In India, wheat is typically sold in its husk, and this is separated from 
the grain and discarded during milling. Meats are sold with differing amounts of bones and fat around the world, which affects the proportion edible. In short, the percentage edible of foods often differs across countries because of how they are prepared for sale.

3. People in developing countries often throw away fewer parts of foods than people in the United States, especially in low income countries. In Kenya, for example, people eat the mango skin whereas people throw the mango skin away in most of the world. In Malawi, people eat small dried fish from Lake Malawi in their entirety - bones, head and skin. They also discard a much smaller proportion of green leafy vegetables than is typical in the United States. In Vietnam, the heads of fish are boiled for soup broth and eaten when they are soft, whereas in the United States fish heads are thrown away. In China $5 \%$ of potato is considered inedible (China CDC, 2009) compared with $25 \%$ in the United States (USDA NAL, 2014).

The above discussion means that it is not unusual to need to adjust proportion inedible indicated in the USDA NAL nutrient database, especially for meats, fish, vegetables and fruits and sometimes for cereals. It therefore makes sense to consult the FAO/INFOODS database to see if a national or regional database is available, and to discuss this issue with workers and key informants.

It is relatively easy for researchers to estimate the proportion edible themselves to see if USDA NAL or FAO/INFOODS databases provide a good benchmark for proportion edible, by purchasing food from a local market, weighing the food, and having a local person prepare the food for eating or cooking. Then separately weigh the edible and discarded portions and calculate percentage edible. ${ }^{17}$ This provides a rough check on edible portions.

\subsubsection{Nutritional content of foods (calories, protein, fats, and carbohydrates)}

In order to determine whether a model diet meets nutritional requirements, it is necessary to know the nutritional content of foods and to include this information in the Excel living wage model diet program. The USDA NAL online database is an excellent source on nutritional content for a wide variety of foods. Appendix 3.1 lists the nutritional content for common foods drawn from this database. For convenience average values for different types of rice, fruits and vegetables, beans, etc. are calculated. The FAO/ INFOODS database (discussed above) lists national and regional databases with nutritional information that are sometimes better to use than USDA NAL. For example, the number of calories in milk depends on fat content of milk, which varies across countries depending on the types of 
cows and milk animals. This means that it is preferable to use data from a national food composition database if it is available rather than the USDA NAL database for the nutritional content of milk. Indeed, researchers have used country-specific food composition databases for creating model diets for living wage studies in Bangladesh, China and India.

\subsection{Excel Living Wage Model Diet Program}

We created an Excel model diet program to help researchers create a model diet for estimating a living wage that is nutritious, consistent with local food preferences, and relatively low in cost for a nutritious diet. The Excel program includes four worksheets - to be used in order. The remainder of this section describes each worksheet - its primary aim, required inputs, and resulting outputs. This program is available on the Edward Elgar website.

\subsubsection{Excel model diet program: Worksheet 1 (data entry and creation of a preliminary diet with sufficient calories)}

There are two aims of this worksheet: (i) to input all data needed for the program and (ii) to develop an initial diet with the required number of calories per person.

3.8.1.1 Required number of calories per person The number of calories required per person is entered at the top of Worksheet 1. This value is taken from the Excel calorie requirements program.

3.8.1.2 Starting diet The starting diet should be based on another source. This can be either a model diet for the country/location or a diet based on food consumption from a recent household expenditure survey. ${ }^{18}$ Using a country- or location-specific starting diet is important because such a diet usually contains quantities of foods commonly consumed in the study location.

3.8.1.3 Enter whether starting diet is in purchased grams or edible grams Quantities for each food in the starting diet can be inputted either in purchased grams or edible grams. Diets from household expenditure surveys are often stated in purchased grams, whereas diets from nutritionists are almost always stated in edible grams. When purchased grams are entered, the Excel program automatically calculates the number of edible grams. When edible grams are entered, the Excel program automatically calculates the number of purchased grams. 
3.8.1.4 Select a small number of food items to represent each major food group group Instructions in the Excel model diet program indicate the number of food items to include in each major group. When the data source for the starting diet has more food items in a major food group than the living wage model diet, the total number of grams in the major food group should be distributed equally over the food items included in the Excel model diet program. For example, if the data source includes 20 grams for each of 5 different fruits, the two common fruits selected for the model diet should have 50 grams each to begin with.

\subsubsection{Additional inputs}

- Nutritional composition of each food item (number of calories, proteins, fats and carbohydrates per 100 grams)

- Proportion edible for each food item (1 is used when no inedible parts)

- Percentage to add to cost for salt, spices, sauces, and condiments

- Percentage to add to cost for some additional variety

- Percentage to add to cost for minimal wastage and spoilage

- Cost per kilo of each food item based on a local market survey

- Percentage distribution of food costs from another source such as household survey or another model diet

\subsubsection{Adjustment made in Worksheet 1 to ensure required number of} calories Worksheet 1 automatically adjusts initial quantities in the starting diet so that this diet includes the required number of calories. For example, if a starting diet contains 2000 calories and calorie requirements call for 2200 calories, the quantity for each food item in the input diet would be increased by $10 \%$ (i.e. increased by 2200 required calories divided by 2000 calories found in the diet before adjustment). It is worth noting that the most common methodology for estimating food costs for poverty lines and living wages stops right here.

\subsubsection{Excel model diet program: Worksheet 2 (adjustments to make the diet nutritious in more than only calories)}

The main purpose of Worksheet 2 is to adjust the model diet from Worksheet 1 so that it is nutritious in terms of macronutrients (acceptable percentages of calories from proteins, fats, and carbohydrates) and micronutrients (minimum number of grams of vegetables and fruits) and has reasonable and healthy amounts of sugar, oils and fats, dairy, and coffee/tea. Worksheet 2 begins with the model diet with required number of calories carried over from Worksheet 1 . The diet at this point is rarely nutritious unless the starting diet was a model diet from nutritionists. 
3.8.2.1 Useful nutritional indicators calculated on Worksheet 2 There are a number of useful indicators calculated in Worksheet 2 to help researchers evaluate whether the diet meets nutritional recommendations. These include:

- Number of grams of proteins, fats and carbohydrates from each food item and in total

- Percentage of calories from proteins, fats and carbohydrates in the model diet

- Total number of grams of fruits, vegetables, and legumes

3.8.2.2 Iterative process to develop a model diet that meets nutritional requirement and is palatable The iterative process involves the analyst changing quantities of edible grams of food items included in the model diet, so that nutritional requirements are met while keeping the diet palatable. Suggestions for quantities of each food group to include are provided in the Excel sheet, but these are general suggestions partly based on experience, and are not hard and fast rules. Each time a change is made, the analyst can check how that change affected the percentage of calories coming from proteins, fats and carbohydrates in the model diet.

- To begin with, the analyst should change numbers of edible grams in such a way that amounts of sugar, oils, fruits and vegetables, coffee/ tea and milk are reasonable and healthy. Often, the amount of sugar decreases and amounts of fruits and vegetables and milk increase.

- Next, amounts of protein-rich foods should be adjusted so that percentage of calories from proteins, fats and carbohydrates all fall within desired ranges.

Note that none of the above changes will affect the total number of calories in the model diet because the Excel model diet program automatically adjusts the amount of cereals to keep total calories constant.

\subsubsection{Excel model diet program: Worksheet 3 (adjustments for relative prices and distribution of food costs)}

The purpose of Worksheet 3 is to ensure that the final model diet is relatively inexpensive for a nutritious diet. Worksheet 3 begins with the model diet carried over from Worksheet 2 that is palatable and nutritious in terms of calories, macronutrients and fruits and vegetables. Worksheet 3 includes indicators of relative food prices and costs, which are useful for helping to decide how to reduce the cost of the model diet while maintaining its nutritional value. These indicators include: 
- Cost per protein of each food

- Cost per calorie of each food

- Percentage of the cost of the model diet for each food

- Percentage distribution of food costs by food group from another source

- Total cost of the model diet

In Worksheet 3, the diet is change in an iterative way to reduce costs while keeping similar nutritional values. This process has four steps:

STEP 1: Substitute less expensive protein-rich foods for more expensive protein-rich foods.

Protein-rich foods are almost always among the most expensive foods in a model diet, and there are often large differences between costs of different protein-rich foods. Step 1 begins with an examination of the cost per protein for protein-rich foods (pulses/beans/tofu, meats/fish, eggs, and dairy). Based on relative costs per protein of protein-rich foods, quantities of these foods should be adjusted (with possibility of dropping an especially expensive protein-rich food), so that there are greater quantities of less expensive protein-rich foods and smaller quantities of more expensive ones, while keeping a similar percentage of calories from proteins. In this way the cost of the model diet can be reduced without affecting the amount of protein. Some animal-based foods, including milk for children, should remain in the diet even when they are relatively expensive. However, it is important to keep local preferences in mind when making these adjustments, so that, for example, not all meat should be replaced by eggs even when eggs are the less expensive. For the same reason, it is important to limit amounts of legumes. Percentages of calories from proteins, fats, and carbohydrates from Worksheet 2 are shown on Worksheet 3 so that the effects of changes in the nutritional content of the model diet in Worksheet 3 can be easily seen. Step 1 sometimes results in a sizable reduction in the cost of the model diet.

STEP 2: Substitute other less expensive foods for more expensive foods.

A further reduction in the cost of the model diet while maintaining its nutritious nature can often be achieved by:

- Adjusting the distribution of the amounts of prepared cereals, roots and tubers, and starchy plantains (foods high in carbohydrates) depending on their relative cost per calorie. Prepared cereals such as bread and pasta are more expensive than unprepared cereals. However, local norms need to be kept in mind about whether people typically prepare pasta and bread from scratch or buy them, and how much of these they eat. 
- Increasing the amount of oil if the percentage of calories from fats in the model diet is low (below 20\%) and the cost per calorie of oil is lower than the cost per calorie of the main cereal.

STEP 3: Limit the percentage of total food costs spent for each food or food group.

The percentage of the cost of a model diet for each food and food group can be a very useful indicator for assessing the reasonableness of a model diet. If this percentage is too high for any food or food group, it is usually advisable to reduce the amount for that food item or food group in the model diet. For example, if the cost of animal-based foods is greater than $45-50 \%$ of the cost of the model diet, the amount of animal-based foods should usually be reduced.

STEP 4: Compare the percentage distribution of food costs in the model diet with the percentage distribution of food costs from another source.

This serves as a further check on how reasonable the model diet is. Large differences between the percentage distribution of food costs by food groups in the model diet compared with the percentage distribution from another source (entered in Worksheet 1) should be explainable or lead to adjustments in the living wage model diet.

\subsubsection{Excel model diet program: Worksheet 4 (final diet)}

Worksheet 4 displays the final model diet, the cost of each food item, and the total cost of the model diet with and without additional costs for salt, spices and condiments, waste and spoilage, and additional variety.

\subsection{Hypothetical Example: Creating a Living Wage Model Diet}

This example is roughly based on the model diet developed in the Kenya living wage study for the Lake Naivasha area. Prices of foods and amounts in the initial starting diet have been changed for illustrative purposes.

\subsubsection{Worksheet 1. Entering required information and setting initial diet}

3.9.1.1 Initial diet and assumptions The starting diet we used was the poverty line diet for urban Kenya (KNBS, 2007), which was based on food consumption of urban households according to a household expenditure survey. This diet included 34 foods, which we aggregated into 11 major food groups. The foods we selected to represent each food group were acceptable foods with the lowest cost per edible gram for the food group found from a local food market survey carried out as part of a living wage study. We included only beef in the meat/fish group, because people did not eat much fish in the part of the Kenya we focused on. 
The 2288 calories per person entered at the top of Worksheet 1 (not shown in Table 3.3) was calculated in the Excel calorie requirement program. Percentages for miscellaneous food costs entered at the bottom of Worksheet 1 were $11 \%$ for variety, 3\% for waste/spoilage, and $1 \%$ for salt/spices/condiments (as found in a recent household expenditure survey). Nutritional content and proportion edible were taken from the USDA NAL online database. Cost per kilo of each food item was based on our local market survey of food prices. Since this is a hypothetical example, prices were changed to better illustrate use of the Excel model diet program.

\subsubsection{Adjusting number of edible grams to ensure total calories} required The starting diet contained 2095 calories, which was less than the 2288 calories required (calculated by the calorie requirement Excel program). This meant that the number of grams of each food in the initial diet was automatically increased by a factor of 2288/2095 on Worksheet 1 . Table 3.3 is taken from Worksheet 1 , which displays both the original number of edible grams and the number of edible grams in the adjusted diet.

\subsubsection{Worksheet 2. Adjusting initial model diet to ensure acceptable nutrition in addition to required calories}

Worksheet 2 begins with the adjusted initial diet from Worksheet 1 that contains the required number of calories. Nutritional adjustments were made on Worksheet 2, which resulted in a new model diet that meets nutritional requirements, is consistent with Kenya's development level and food preferences, and keeps the total number of calories the same. Worksheet 2 is displayed in Table 3.4. The main differences between the diet from Worksheet 1 and the diet developed in Worksheet 2 were: (1) decreases in amounts of sugar, tea, egg, and meats and (2) increases in amounts of milk, maize meal, fruits and vegetables. The decrease in sugar was because a living wage model diet generally limits sugar to 30 grams per person per day, which is less than people in urban Kenya currently consume. The decrease in tea was because we assumed 2 cups of tea per day for adults. Decreases in quantities of egg and meats came about to keep the percentage of calories from proteins reasonable for a low income country. Milk was increased to allow children 1 cup of milk per day and adults $1 / 4$ cup per day for tea. Note that it is not uncommon to see an increase in milk in living wage model diets, because the nutritional standard for milk is often higher than the amount consumed in low income countries. Fruits and vegetables were increased to a total of 325 grams per day including legumes to ensure sufficient micronutrients. The increase in the quantity of maize meal occurs because the Excel program automatically adjusts the value of the main cereal to maintain the required number of calories. As a 


\begin{tabular}{|c|c|c|c|c|c|c|c|}
\hline 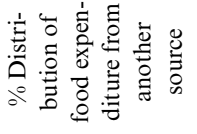 & $\begin{array}{l}\text { iे } \\
\text { तें }\end{array}$ & लें & oे & & $\stackrel{\text { 亏ें }}{\dot{+}}$ & $\begin{array}{l}\text { aे } \\
\stackrel{2}{\Xi}\end{array}$ & \\
\hline 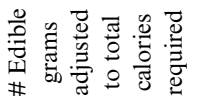 & 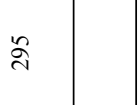 & $\stackrel{\curvearrowright}{ }$ & $\stackrel{\text { a }}{ }$ & & $\stackrel{\sim}{i}$ & I & \\
\hline 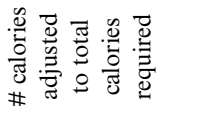 & dั & 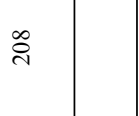 & వ & & \& & $\hat{\infty}$ & \\
\hline 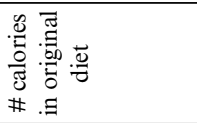 & $\stackrel{n}{a}$ & $\bar{\Xi}$ & $\Sigma$ & & $\infty$ & I & \\
\hline 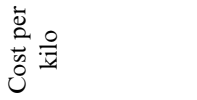 & ?. & $\stackrel{\circ}{\stackrel{+}{I}}$ & $\stackrel{\circ}{\stackrel{i}{d}}$ & & 움 & : & \\
\hline 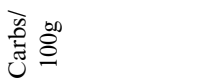 & ڤે & $\stackrel{+}{\dot{q}}$ & $\stackrel{n}{\check{n}}$ & & 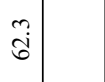 & $\stackrel{\infty}{+}$ & \\
\hline 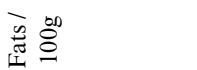 & $\dot{m}$ & $\stackrel{m}{m}$ & $\overrightarrow{0}$ & & $\stackrel{\infty}{-}$ & $m$ & \\
\hline 일 & $\stackrel{m}{\varrho}$ & $\stackrel{\partial}{\infty}$ & $\stackrel{\circ}{i}$ & & $\stackrel{\sim}{\sim}$ & $\stackrel{\sim}{m}$ & \\
\hline 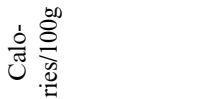 & $\vec{ర}$ & $\stackrel{n}{\sim}$ & $\Sigma$ & & g & $\vec{\sigma}$ & \\
\hline 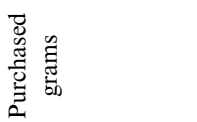 & 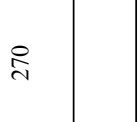 & $\mathbb{N}$ & $\tilde{m}$ & & $\stackrel{\sim}{\Delta}$ & $\stackrel{\oplus}{=}$ & \\
\hline 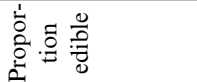 & - & - & $\stackrel{n}{a}$ & & - & - & \\
\hline 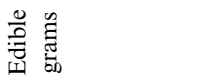 & $\stackrel{ }{\stackrel{2}{*}}$ & 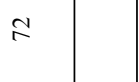 & 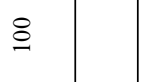 & & $\stackrel{d}{A}$ & 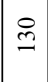 & \\
\hline 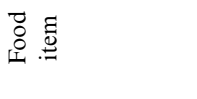 & . & 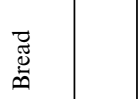 & 蒁 & & $\begin{array}{l}0 \\
\tilde{\Xi} \\
\infty \\
\infty\end{array}$ & $\stackrel{y}{\Xi}$ & \\
\hline 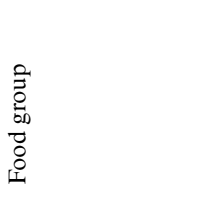 & 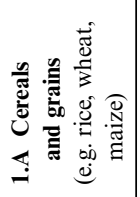 & 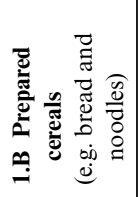 & 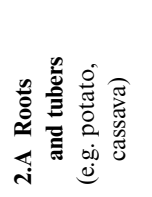 & 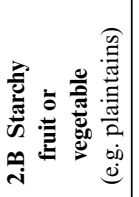 & 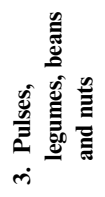 & & 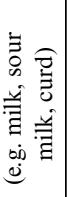 \\
\hline
\end{tabular}




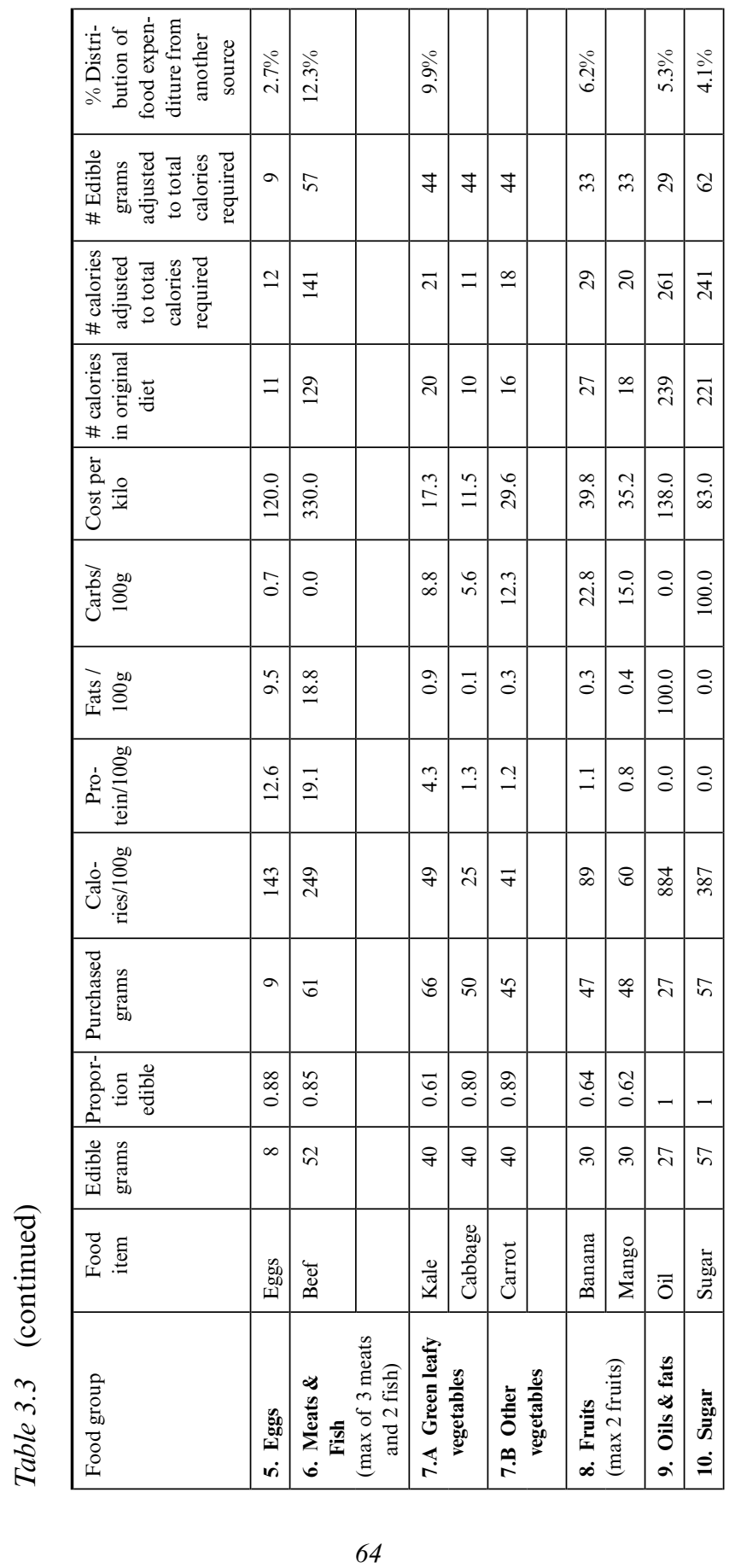




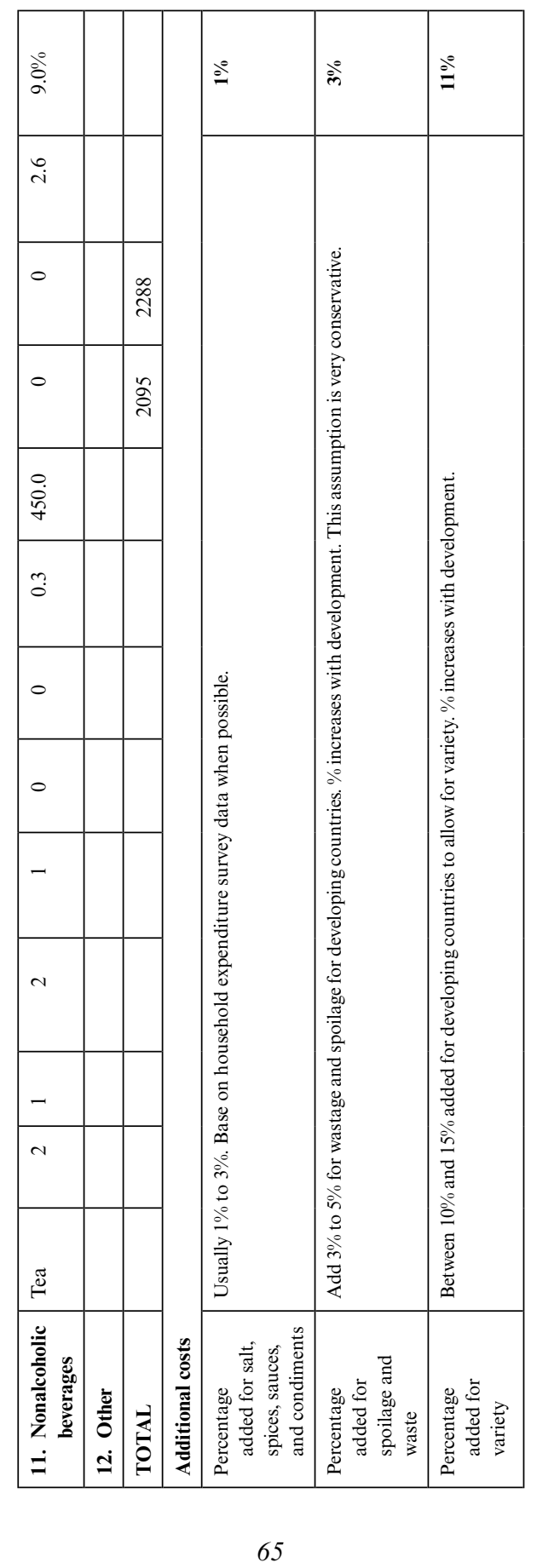

Richard Anker and Martha Anker - 9781786431462 Downloaded from PubFactory at 04/26/2023 08:40:10AM 
Table 3.4 Worksheet 2. Nutrition adjustments

\begin{tabular}{|c|c|c|c|c|c|c|c|}
\hline Food group & Food item & $\begin{array}{c}\text { \# Grams } \\
\text { edible adjusted } \\
\text { to total calories } \\
\text { required } \\
\text { (output } \\
\text { from calorie } \\
\text { adjustment } \\
\text { worksheet) }\end{array}$ & $\begin{array}{c}\text { Grams } \\
\text { edible } \\
\text { with } \\
\text { adjust- } \\
\text { ments for } \\
\% \mathrm{P}, \% \mathrm{~F} \text {, } \\
\% \mathrm{C}, \& \\
\text { judgement }\end{array}$ & $\begin{array}{l}\text { Suggestions on } \\
\text { quantities } \\
\text { to use } \\
\text { t }\end{array}$ & $\begin{array}{l}\text { Expla- } \\
\text { nation of } \\
\text { adjust- } \\
\text { ments } \\
\text { made }\end{array}$ & $\begin{array}{l}\text { Calories/ } \\
100 \mathrm{~g}\end{array}$ & $\begin{array}{l}\text { Calories } \\
\text { in work- } \\
\text { sheet } \\
1 \text { diet }\end{array}$ \\
\hline $\begin{array}{l}\text { 1.A Cereals and } \\
\text { grains } \\
\text { (for example: rice, } \\
\text { wheat, maize) }\end{array}$ & Maize & 295 & 324 & $\begin{array}{l}\text { No changes } \\
\text { allowed for main } \\
\text { cereal }\end{array}$ & & 361 & 1064 \\
\hline $\begin{array}{l}\text { 1.B Prepared } \\
\text { cereals } \\
\text { (for example: } \\
\text { bread and } \\
\text { noodles) }\end{array}$ & Bread & 79 & 79 & $\begin{array}{l}\text { Use appropriate } \\
\text { number of slices } \\
\text { or rolls }\end{array}$ & & 265 & 208 \\
\hline $\begin{array}{l}\text { 2.A Roots and } \\
\text { tubers } \\
\text { (for example: } \\
\text { potato, } \\
\text { cassava) }\end{array}$ & Potato & 109 & 109 & $\begin{array}{l}\text { Amount } \\
\text { depends on } \\
\text { food habits (see } \\
\text { worksheet 1) }\end{array}$ & & 77 & 84 \\
\hline $\begin{array}{l}\text { 2.B Starchy fruit } \\
\text { or vegetable } \\
\text { (for example: } \\
\text { plaintains) }\end{array}$ & & & & $\begin{array}{l}\text { Amount } \\
\text { depends on } \\
\text { food habits (see } \\
\text { worksheet 1) }\end{array}$ & & & \\
\hline $\begin{array}{l}\text { 3. Pulses, } \\
\text { legumes, beans } \\
\text { (for example: } \\
\text { legumes, } \\
\text { beans, nuts) }\end{array}$ & Beans & 26 & 26 & $\begin{array}{l}\text { Usually between } \\
1 \text { and } 2 \text { servings } \\
\text { ( } 28-56 \text { grams) }\end{array}$ & & 343 & 90 \\
\hline $\begin{array}{l}\text { 4. Dairy } \\
\text { (for example: } \\
\text { milk, sour } \\
\text { milk, curd) }\end{array}$ & Milk & 142 & 171 & $\begin{array}{l}\text { Usually at least } \\
1 \text { cup pd for } \\
\text { children and } \\
\text { some milk for } \\
\text { adults for } \\
\text { coffee/tea }\end{array}$ & $\begin{array}{l}1 \text { cup to } \\
\text { age } 16 \& \\
1 / 4 \text { cup } \\
\text { for adults } \\
\text { to use in } \\
\text { tea }\end{array}$ & 61 & 87 \\
\hline 5. Eggs & Eggs & 9 & 更 & $\begin{array}{l}\text { Usually in terms } \\
\text { of number } \\
\text { of eggs pw. } \\
\text { Medium egg } \\
\text { usually around } \\
50 \text { grams }\end{array}$ & $\begin{array}{l}1 \text { per } \\
\text { week }\end{array}$ & 143 & 12 \\
\hline $\begin{array}{l}\text { 6. Meats \& Fish } \\
\text { (maximum of } 3 \\
\text { meats and } 2 \\
\text { fish) }\end{array}$ & Beef & 57 & 更 & $\begin{array}{l}\text { Usually in terms } \\
\text { of number of } \\
\text { servings per } \\
\text { week (a serving } \\
\text { is usually } 85 \\
\text { edible grams). } \\
\text { Quantity of meat } \\
\text { increases with } \\
\text { development }\end{array}$ & $\begin{array}{l}3 \text { meals } \\
\text { per week }\end{array}$ & 249 & 141 \\
\hline
\end{tabular}




\begin{tabular}{|c|c|c|c|c|c|c|c|c|c|c|}
\hline $\begin{array}{l}\text { Calories } \\
\text { in diet }\end{array}$ & $\begin{array}{c}\% \\
\text { Calories } \\
\text { in diet }\end{array}$ & $\begin{array}{c}\text { Protiens/ } \\
100 \mathrm{~g}\end{array}$ & $\begin{array}{c}\text { Grams } \\
\text { protiens } \\
\text { in work- } \\
\text { sheet } 1 \\
\text { diet }\end{array}$ & $\begin{array}{l}\text { Grams } \\
\text { proteins } \\
\text { in diet }\end{array}$ & $\begin{array}{l}\text { Fats/ } \\
100 \mathrm{~g}\end{array}$ & $\begin{array}{c}\text { Grams } \\
\text { fat in } \\
\text { worksheet } \\
1 \text { diet }\end{array}$ & $\begin{array}{c}\text { Grams } \\
\text { fat in } \\
\text { diet }\end{array}$ & $\begin{array}{c}\text { Carbs/ } \\
100 \mathrm{~g}\end{array}$ & $\begin{array}{c}\text { Grams } \\
\text { carbs in } \\
\text { worksheet } \\
1 \text { diet }\end{array}$ & $\begin{array}{c}\text { Grams } \\
\text { carbs in } \\
\text { diet }\end{array}$ \\
\hline 1170 & 51.1 & 10.3 & 30.4 & 33.4 & 3.9 & 11.5 & 12.6 & 76.9 & 226.8 & 249 \\
\hline 208 & 9.1 & 8.9 & 7.0 & 7.0 & 3.3 & 2.6 & 2.6 & 49.4 & 38.8 & 39 \\
\hline 84 & 3.7 & 2.0 & 2.2 & 2.2 & 0.1 & 0.1 & 0.1 & 17.5 & 19.1 & 19 \\
\hline 90 & 3.9 & 21.2 & 5.6 & 5.6 & 1.8 & 0.5 & 0.5 & 62.3 & 16.3 & 16 \\
\hline 104 & 4.6 & 3.2 & 4.5 & 5.5 & 3.3 & 4.7 & 5.6 & 4.8 & 6.8 & 8 \\
\hline 9 & 0.4 & 12.6 & 1.1 & 0.8 & 9.5 & 0.8 & 0.6 & 0.7 & 0.1 & 0 \\
\hline 91 & 4.0 & 19.1 & 10.8 & 7.0 & 18.8 & 10.7 & 6.8 & 0.0 & 0.0 & 0 \\
\hline
\end{tabular}


Table 3.4 (continued)

\begin{tabular}{|c|c|c|c|c|c|c|c|}
\hline Food group & Food item & $\begin{array}{c}\text { \# Grams } \\
\text { edible adjusted } \\
\text { to total calories } \\
\text { required } \\
\text { (output } \\
\text { from calorie } \\
\text { adjustment } \\
\text { worksheet) }\end{array}$ & $\begin{array}{l}\text { Grams } \\
\text { edible } \\
\text { with } \\
\text { adjust- } \\
\text { ments for } \\
\% \mathrm{P}, \% \mathrm{~F} \text {, } \\
\% \mathrm{C}, \& \\
\text { judgement }\end{array}$ & $\begin{array}{l}\text { Suggestions on } \\
\text { quantities } \\
\text { to use } \\
\text { t }\end{array}$ & $\begin{array}{l}\text { Expla- } \\
\text { nation of } \\
\text { adjust- } \\
\text { ments } \\
\text { made }\end{array}$ & $\begin{array}{l}\text { Calories/ } \\
100 \mathrm{~g}\end{array}$ & $\begin{array}{c}\text { Calories } \\
\text { in work- } \\
\text { sheet } \\
1 \text { diet }\end{array}$ \\
\hline \multirow[t]{2}{*}{$\begin{array}{l}\text { 7.A Green leafy } \\
\text { vegetables }\end{array}$} & Kale & 44 & 66 & $\begin{array}{l}\text { At least } 1 \text { GLV } \\
\text { and } 1 \text { fruit. }\end{array}$ & $\begin{array}{l}\text { Increased } \\
\text { all fruits }\end{array}$ & 49 & 21 \\
\hline & Cabbage & 44 & 66 & Minimum 300 & and & 25 & 11 \\
\hline $\begin{array}{l}\text { 7.B Other } \\
\text { vegetables }\end{array}$ & Carrot & 44 & 66 & $\begin{array}{l}\text { grams of fruits } \\
\text { plus vegetables } \\
\text { plus legumes }\end{array}$ & $\begin{array}{l}\text { vegetables } \\
\text { by } 15.4 \\
\text { to ensure }\end{array}$ & 41 & 18 \\
\hline \multirow[t]{2}{*}{ 8. Fruits } & Banana & 33 & 50 & Increase by 25 & 325 & 89 & 29 \\
\hline & Mango & 33 & 50 & $\begin{array}{l}\text { grams for each } \\
\text { development } \\
\text { level }\end{array}$ & $\begin{array}{l}\text { grams of } \\
\text { legumes, } \\
\text { fruits and } \\
\text { vegetables }\end{array}$ & 60 & 20 \\
\hline 9. Oils \& fats & Oil & 29 & 30 & $\begin{array}{l}\text { Usually } 30-34 \\
\text { grams. It can be } \\
\text { lower if }>15 \% \\
\text { fats in diet }\end{array}$ & 30 usual & 884 & 261 \\
\hline 10. Sugar & Sugar & 62 & 30 & $\begin{array}{l}\text { Usually between } \\
24 \text { and } 30 \text { grams }\end{array}$ & $\begin{array}{l}30 \text { is usual } \\
\text { maximum }\end{array}$ & 387 & 241 \\
\hline $\begin{array}{l}\text { 11. Nonalcoholic } \\
\text { beverages }\end{array}$ & Tea & 2.6 & 2.6 & $\begin{array}{l}\text { No soft drinks. } \\
\text { Tea } 2 \text { grams and } \\
\text { coffee } 7 \text { grams } \\
\text { per cup. Usually } \\
2 \text { cups pd for } \\
\text { adults }\end{array}$ & $\begin{array}{l}2 \text { cups per } \\
\text { adult per } \\
\text { day }\end{array}$ & 1 & 0 \\
\hline 12. Other & & & & $\begin{array}{l}\text { No cakes or } \\
\text { confection }\end{array}$ & & & \\
\hline TOTAL & & $\begin{array}{l}\text { Fruits }+ \\
\text { vegetables }+ \\
\text { legumes }\end{array}$ & 325 & & & & 2288 \\
\hline
\end{tabular}

result of these changes, the new diet in Worksheet 2 had $11.7 \%$ of calories from proteins, which was not too far from our $11-12 \%$ target; $23.6 \%$ of calories came from fats and $64.7 \%$ of from carbohydrates, all of which were within required ranges.

\subsubsection{Worksheet 3. Taking relative food prices into account}

The purpose of Worksheet 3 is to: (i) change the mix of foods to make the diet less expensive, while maintaining nutritional standards, and (ii) check that the percentage distribution of food expenditures in the model 


\begin{tabular}{|c|c|c|c|c|c|c|c|c|c|c|}
\hline $\begin{array}{c}\text { Calories } \\
\text { in diet }\end{array}$ & $\begin{array}{c}\% \\
\text { Calories } \\
\text { in diet }\end{array}$ & $\begin{array}{c}\text { Protiens/ } \\
100 \mathrm{~g}\end{array}$ & $\begin{array}{l}\text { Grams } \\
\text { protiens } \\
\text { in work- } \\
\text { sheet } 1 \\
\text { diet }\end{array}$ & $\begin{array}{c}\text { Grams } \\
\text { proteins } \\
\text { in diet }\end{array}$ & $\begin{array}{l}\text { Fats/ } \\
100 \mathrm{~g}\end{array}$ & $\begin{array}{c}\text { Grams } \\
\text { fat in } \\
\text { worksheet } \\
1 \text { diet }\end{array}$ & $\begin{array}{l}\text { Grams } \\
\text { fat in } \\
\text { diet }\end{array}$ & $\begin{array}{l}\text { Carbs } \\
/ 100 \mathrm{~g}\end{array}$ & $\begin{array}{c}\text { Grams } \\
\text { carbs in } \\
\text { worksheet } \\
1 \text { diet }\end{array}$ & $\begin{array}{c}\text { Grams } \\
\text { carbs in } \\
\text { diet }\end{array}$ \\
\hline
\end{tabular}

\begin{tabular}{|c|c|c|c|c|c|c|c|c|c|c|}
\hline 33 & 1.4 & 4.3 & 1.9 & 2.9 & 0.9 & 0.4 & 0.6 & 8.8 & 3.8 & 6 \\
\hline 17 & 0.7 & 1.3 & 0.6 & 0.9 & 0.1 & 0.0 & 0.1 & 5.6 & 2.4 & 4 \\
\hline 27 & 1.2 & 1.2 & 0.5 & 0.8 & 0.3 & 0.1 & 0.2 & 12.3 & 5.4 & 8 \\
\hline 44 & 1.9 & 1.1 & 0.4 & 0.5 & 0.3 & 0.1 & 0.1 & 22.8 & 7.5 & 11 \\
\hline 30 & 1.3 & 0.8 & 0.3 & 0.4 & 0.4 & 0.1 & 0.2 & 15.0 & 4.9 & 7 \\
\hline 265 & 11.6 & 0.0 & 0.0 & 0.0 & 100.0 & 29.5 & 30.0 & 0.0 & 0.0 & 0 \\
\hline 116 & 5.1 & 0.0 & 0.0 & 0.0 & 0.0 & 0.0 & 0.0 & 100.0 & 62.3 & 30 \\
\hline 0 & 0.0 & 0.0 & 0.0 & 0.0 & 0.0 & 0.0 & 0.0 & 0.3 & 0.0 & 0 \\
\hline \multirow[t]{2}{*}{2288} & & & 65.2 & 67.0 & & 61.2 & 60.1 & & 394.2 & 398 \\
\hline & & & $11.4 \%$ & $11.7 \%$ & & $24.1 \%$ & $23.6 \%$ & & $64.5 \%$ & $64.7 \%$ \\
\hline
\end{tabular}

diet is not very different than the distribution from another source, unless there is a good explanation and justification for the differences. Worksheet 3 is shown in Table 3.5. In the first step we reduced the cost of protein-rich foods. The cost per protein of beans was around one-sixth the cost per protein of meat, and the cost per protein of eggs was about half the cost per protein of meat. Therefore we increased the amount of beans to one and a half portions per day and eggs to two per week, and reduced meat to two portions per week. Note that despite these changes, the percentage of calories from proteins remained unchanged. The only 


\section{Table 3.5 Worksheet 3. Taking prices into account}

\begin{tabular}{|c|c|c|c|c|c|c|c|c|}
\hline Food Groups & $\begin{array}{l}\text { Food } \\
\text { item }\end{array}$ & $\begin{array}{l}\text { \# Edible } \\
\text { grams } \\
\text { from } \\
\text { work- } \\
\text { sheet } 2 \\
\text { diet }\end{array}$ & $\begin{array}{c}\text { Final grams } \\
\text { edible with } \\
\text { adjustments } \\
\text { for } \% \mathrm{P}, \text { quality } \\
\% \mathrm{P}, \% \mathrm{~F}, \% \mathrm{C} \\
\& \text { relative food } \\
\text { prices }\end{array}$ & $\begin{array}{l}\text { Expla- } \\
\text { nation } \\
\text { of final } \\
\text { adjust- } \\
\text { ments }\end{array}$ & $\begin{array}{c}\text { \# Grams } \\
\text { pur- } \\
\text { chased }\end{array}$ & $\begin{array}{l}\text { Calories/ } \\
100 \mathrm{~g}\end{array}$ & $\begin{array}{l}\text { Calories } \\
\text { in final } \\
\text { diet }\end{array}$ & $\begin{array}{c}\% \\
\text { Calories } \\
\text { final } \\
\text { diet }\end{array}$ \\
\hline $\begin{array}{l}\text { 1.A Cereals } \\
\text { and grains } \\
\text { (for example: } \\
\text { rice, wheat, } \\
\text { maize) }\end{array}$ & Maize & 324 & 344 & & 344 & 361 & 1242 & 54.3 \\
\hline $\begin{array}{l}\text { 1.B Prepared } \\
\text { cereals } \\
\text { (for example: } \\
\text { bread and } \\
\text { noodles) }\end{array}$ & Bread & 79 & 42 & $\begin{array}{l}\text { Reduced } \\
\text { to } 2 \text { slices } \\
\text { per day }\end{array}$ & 42 & 265 & 111 & 4.9 \\
\hline $\begin{array}{l}\text { 2.A Roots and } \\
\text { tubers } \\
\text { (for example: } \\
\text { potato, cassava) } \\
\text { 2.B Starchy fruit } \\
\text { or vegetable } \\
\text { (for example: } \\
\text { plaintains) }\end{array}$ & Potato & 109 & 109 & & 146 & 77 & 84 & 3.7 \\
\hline $\begin{array}{l}\text { 3. Pulses, } \\
\text { legumes, } \\
\text { beans } \\
\text { (for example: } \\
\text { legumes, beans, } \\
\text { nuts) }\end{array}$ & Beans & 26 & 42 & $\begin{array}{l}\text { Increased } \\
\text { to } 1.5 \\
\text { portions } \\
\text { per day as } \\
\text { inexpensive } \\
\text { protein }\end{array}$ & 42 & 343 & 144 & 6.3 \\
\hline $\begin{array}{l}\text { 4. Dairy } \\
\text { (for example: } \\
\text { milk, sour milk, } \\
\text { curd) }\end{array}$ & Milk & 171 & 171 & & 171 & 61 & 104 & 4.6 \\
\hline 5. Eggs & Eggs & 6 & 13 & $\begin{array}{l}\text { Increased } \\
\text { to } 2 \text { eggs } \\
\text { per week }\end{array}$ & 15 & 143 & 19 & 0.8 \\
\hline $\begin{array}{l}\text { 6. Meats \& Fish } \\
\text { (maximum of } 3 \\
\text { meats and } 2 \text { fish) }\end{array}$ & Beef & 36 & 24 & $\begin{array}{l}\text { Reduced } \\
\text { to } 2 \\
\text { portions } \\
\text { per week }\end{array}$ & 28 & 249 & 60 & 2.6 \\
\hline $\begin{array}{l}\text { 7.A Green leafy } \\
\text { vegetables }\end{array}$ & Kale & 66 & 63 & & 103 & 49 & 31 & 1.3 \\
\hline $\begin{array}{l}\text { 7.B Other } \\
\text { vegetables }\end{array}$ & $\begin{array}{l}\text { Cabbage } \\
\text { Carrot }\end{array}$ & $\begin{array}{l}66 \\
66\end{array}$ & $\begin{array}{l}63 \\
63\end{array}$ & & $\begin{array}{l}79 \\
71\end{array}$ & $\begin{array}{l}25 \\
41\end{array}$ & $\begin{array}{l}16 \\
26\end{array}$ & $\begin{array}{l}0.7 \\
1.1\end{array}$ \\
\hline 8. Fruits & $\begin{array}{l}\text { Banana } \\
\text { Mango }\end{array}$ & $\begin{array}{l}50 \\
50\end{array}$ & $\begin{array}{l}47 \\
47\end{array}$ & & $\begin{array}{l}74 \\
76\end{array}$ & $\begin{array}{l}89 \\
60\end{array}$ & $\begin{array}{l}42 \\
28\end{array}$ & $\begin{array}{l}1.8 \\
1.2\end{array}$ \\
\hline
\end{tabular}




\begin{tabular}{|c|c|c|c|c|c|c|c|c|c|c|}
\hline $\begin{array}{c}\text { Protein/ } \\
100 \mathrm{~g}\end{array}$ & $\begin{array}{l}\text { Grams } \\
\text { proteins } \\
\text { final diet }\end{array}$ & $\begin{array}{l}\text { Fats/ } \\
100 \mathrm{~g}\end{array}$ & $\begin{array}{c}\text { Grams } \\
\text { fat final } \\
\text { diet }\end{array}$ & $\begin{array}{c}\text { Carbs/ } \\
100 \mathrm{~g}\end{array}$ & $\begin{array}{l}\text { Grams } \\
\text { carbs } \\
\text { final diet }\end{array}$ & $\begin{array}{l}\text { Cost } \\
\text { per } \\
\text { kilo }\end{array}$ & $\begin{array}{c}\% \text { Distribu- } \\
\text { tion of food } \\
\text { expen- } \\
\text { diture } \\
\text { from } \\
\text { another } \\
\text { source }\end{array}$ & $\begin{array}{c}\% \\
\text { Distribu- } \\
\text { tion of } \\
\text { costs in } \\
\text { model } \\
\text { diet }\end{array}$ & $\begin{array}{c}\text { Cost per } \\
\text { protien } \\
\text { final } \\
\text { model } \\
\text { diet }\end{array}$ & $\begin{array}{c}\text { Cost per } \\
\text { calorie } \\
\text { final } \\
\text { model } \\
\text { diet }\end{array}$ \\
\hline 10.3 & 35.4 & 3.9 & 13.4 & 76.9 & 265 & 37 & $23.5 \%$ & $19.8 \%$ & 0.35 & 0.010 \\
\hline 8.9 & 3.7 & 3.3 & 1.4 & 49.4 & 21 & 124 & $7.3 \%$ & $8.2 \%$ & 1.39 & 0.047 \\
\hline 2.0 & 2.2 & 0.1 & 0.1 & 17.5 & 19 & 24 & $5.0 \%$ & $5.5 \%$ & 1.60 & 0.042 \\
\hline 21.19 & 8.9 & 1.8 & 0.8 & 62.3 & 26 & 75 & $4.9 \%$ & $5.0 \%$ & 0.35 & 0.022 \\
\hline 3.2 & 5.5 & 3.3 & 5.6 & 4.8 & 8 & 60 & $17.9 \%$ & $16.1 \%$ & 1.88 & 0.098 \\
\hline 12.6 & 1.6 & 9.5 & 1.2 & 0.7 & 0 & 120 & $2.7 \%$ & $2.8 \%$ & 1.08 & 0.095 \\
\hline 19.1 & 4.6 & 18.8 & 4.5 & 0.0 & 0 & 330 & $12.3 \%$ & $14.7 \%$ & 2.03 & 0.156 \\
\hline 4.3 & 2.7 & 0.9 & 0.6 & 8.8 & 6 & 17 & $9.9 \%$ & $2.8 \%$ & 0.66 & 0.058 \\
\hline 1.3 & 0.8 & 0.1 & 0.1 & 5.6 & 4 & 12 & $0.0 \%$ & $1.4 \%$ & 1.11 & 0.058 \\
\hline 1.2 & 0.8 & 0.3 & 0.2 & 12.3 & 8 & 30 & $0.0 \%$ & $3.3 \%$ & 2.77 & 0.081 \\
\hline 1.1 & 0.5 & 0.3 & 0.1 & 22.8 & 11 & 40 & $6.2 \%$ & $4.6 \%$ & 5.65 & 0.070 \\
\hline 0.8 & 0.4 & 0.4 & 0.2 & 15 & 7 & 35 & $0.0 \%$ & $4.2 \%$ & 7.10 & 0.095 \\
\hline
\end{tabular}


Table 3.5 (continued)

\begin{tabular}{|c|c|c|c|c|c|c|c|c|}
\hline Food Groups & $\begin{array}{l}\text { Food } \\
\text { item }\end{array}$ & $\begin{array}{l}\text { \# Edible } \\
\text { grams } \\
\text { from } \\
\text { work- } \\
\text { sheet } 2 \\
\text { diet }\end{array}$ & $\begin{array}{c}\text { Final grams } \\
\text { edible with } \\
\text { adjustments } \\
\text { for } \% \mathrm{P}, \text { quality } \\
\% \mathrm{P}, \% \mathrm{~F}, \% \mathrm{C} \\
\& \text { relative food } \\
\text { prices }\end{array}$ & $\begin{array}{l}\text { Expla- } \\
\text { nation } \\
\text { of final } \\
\text { adjust- } \\
\text { ments }\end{array}$ & $\begin{array}{c}\# \\
\text { Grams } \\
\text { pur- } \\
\text { chased }\end{array}$ & $\begin{array}{l}\text { Calories/ } \\
100 \mathrm{~g}\end{array}$ & $\begin{array}{c}\text { Calories } \\
\text { in final } \\
\text { diet }\end{array}$ & $\begin{array}{c}\% \\
\text { Calories } \\
\text { final } \\
\text { diet }\end{array}$ \\
\hline 9. Oils \& fats & Oil & 30 & 30 & & 30 & 884 & 265 & 11.6 \\
\hline 10. Sugar & Sugar & 30 & 30 & & 30 & 387 & 116 & 5.1 \\
\hline $\begin{array}{l}\text { 11. Nonalcoholic } \\
\text { beverages } \\
\text { 12. Other }\end{array}$ & Tea & 2 & 2 & & 2 & 1 & 0 & 0.0 \\
\hline TOTAL & & $\begin{array}{l}\text { Fruits }+ \\
\text { vegetables } \\
+ \\
\text { legumes }\end{array}$ & 325 & & & & 2288 & \\
\hline
\end{tabular}

other change in Worksheet 3 was to reduce the amount of bread to two slices a day per person, because bread is expensive relative to maize and discussions with workers indicated that two slices of bread per day was considered decent.

Next, we compared the percentage distribution of costs by major food group for the model diet with the percentage distribution from a household expenditure survey. They were fairly similar - the main difference being that Kenyans spend $9 \%$ of their food budget on non-alcoholic beverages, while only around $1 \%$ is spent on tea in our model diet, most likely due to the consumption of soft drinks, which are not included in our model diet.

Worksheet 3 reduced the cost of the model diet by $10 \%$ (from around KSh81 to KSh73) without substantially changing its nutritional value.

\subsubsection{Worksheet 4. Final diet}

Cost of the model diet is calculated in Worksheet 4 based on the prices entered into Worksheet 1 . This cost was increased by $15 \%$ in this example to allow for some variety, salt, spices, sauces and condiments, and for minimal spoilage and wastage using percentages entered in worksheet 1 . Table 3.6 presents Worksheet 4 .

3.9.4.1 Conclusions The model diet is consistent with local food preferences, level of development, and relative prices in Kenya. 


\begin{tabular}{|c|c|c|c|c|c|c|c|c|c|c|}
\hline $\begin{array}{l}\text { Protein/- } \\
100 \mathrm{~g}\end{array}$ & $\begin{array}{c}\text { Grams } \\
\text { proteins } \\
\text { final diet }\end{array}$ & $\begin{array}{l}\text { Fats/ } \\
100 \mathrm{~g}\end{array}$ & $\begin{array}{c}\text { Grams } \\
\text { fat final } \\
\text { diet }\end{array}$ & $\begin{array}{c}\text { Carbs/ } \\
100 \mathrm{~g}\end{array}$ & $\begin{array}{c}\text { Grams } \\
\text { carbs } \\
\text { final diet }\end{array}$ & $\begin{array}{c}\text { Cost } \\
\text { per } \\
\text { kilo }\end{array}$ & $\begin{array}{l}\% \text { Distribu- } \\
\text { tion of food } \\
\text { expen- } \\
\text { diture } \\
\text { from } \\
\text { another } \\
\text { source }\end{array}$ & $\begin{array}{c}\% \\
\text { Distribu- } \\
\text { tion of } \\
\text { costs in } \\
\text { model } \\
\text { diet }\end{array}$ & $\begin{array}{l}\text { Cost } \\
\text { per } \\
\text { protien } \\
\text { final } \\
\text { model } \\
\text { diet }\end{array}$ & $\begin{array}{c}\text { Cost } \\
\text { per } \\
\text { calorie } \\
\text { final } \\
\text { model } \\
\text { diet }\end{array}$ \\
\hline 0 & 0.0 & 100 & 30.0 & 0 & 0 & 138 & $5.3 \%$ & $6.5 \%$ & - & 0.016 \\
\hline 0 & 0.0 & 0 & 0.0 & 100 & 30 & 83 & $4.1 \%$ & $3.9 \%$ & - & 0.021 \\
\hline 0 & 0.0 & 0 & 0.0 & 0.3 & 0 & 450 & $9.0 \%$ & $1.1 \%$ & - & 45.000 \\
\hline & 67 & & 58.2 & & 404 & & & & & \\
\hline & $11.7 \%$ & & $22.9 \%$ & & $65.4 \%$ & & & & & \\
\hline
\end{tabular}

- Maize meal is central to the model diet. It is an inexpensive source of calories, and it provides $55 \%$ of all calories in the model diet.

- There was relatively little meat (beef) in the model diet in order to keep the diet relatively low in cost.

- Considerable amount of beans (42 grams) is included in the model diet. This helps ensure there is a sufficient number of quality proteins at relatively low-cost because beans are much less expensive per protein compared to beef. Beans are a central part of the Kenyan diet.

- A reasonably large amount of potato is included in the model diet because it is the lowest cost, and most commonly eaten, root and tuber in Kenya.

- Vegetables are represented by carrots, cabbage, and kale. They are plentiful and inexpensive in local markets which helps reduce food costs. It also helps increase calcium and iron as green leafy vegetables, such as kale, are relatively high in these. Note that the $11 \%$ for variety enables workers to purchase a greater variety of vegetables to help ensure a range of micronutrients.

- Quantity of milk is 1 cup per day for children, and a quarter cup per day for adults to add to tea. 


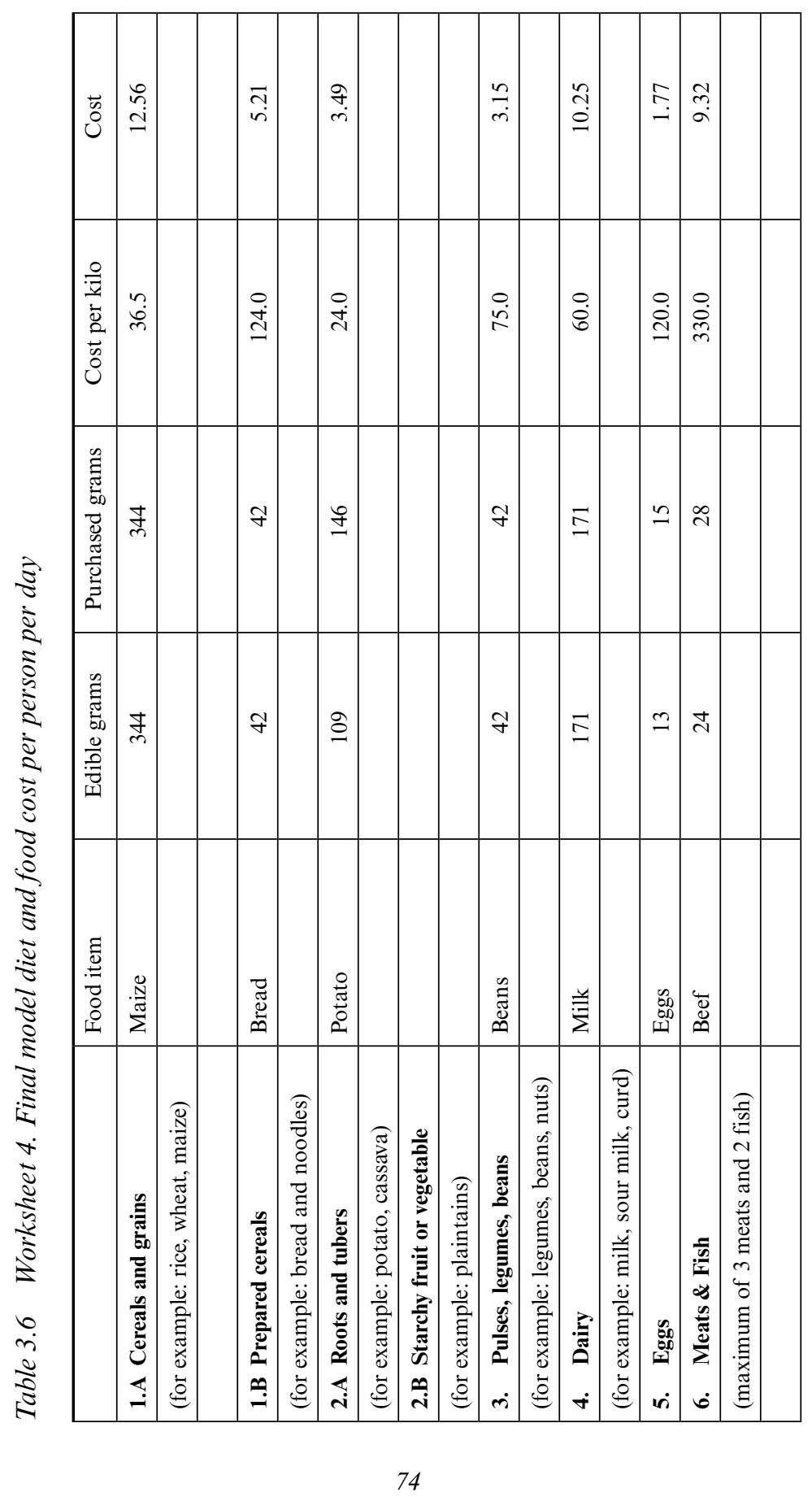




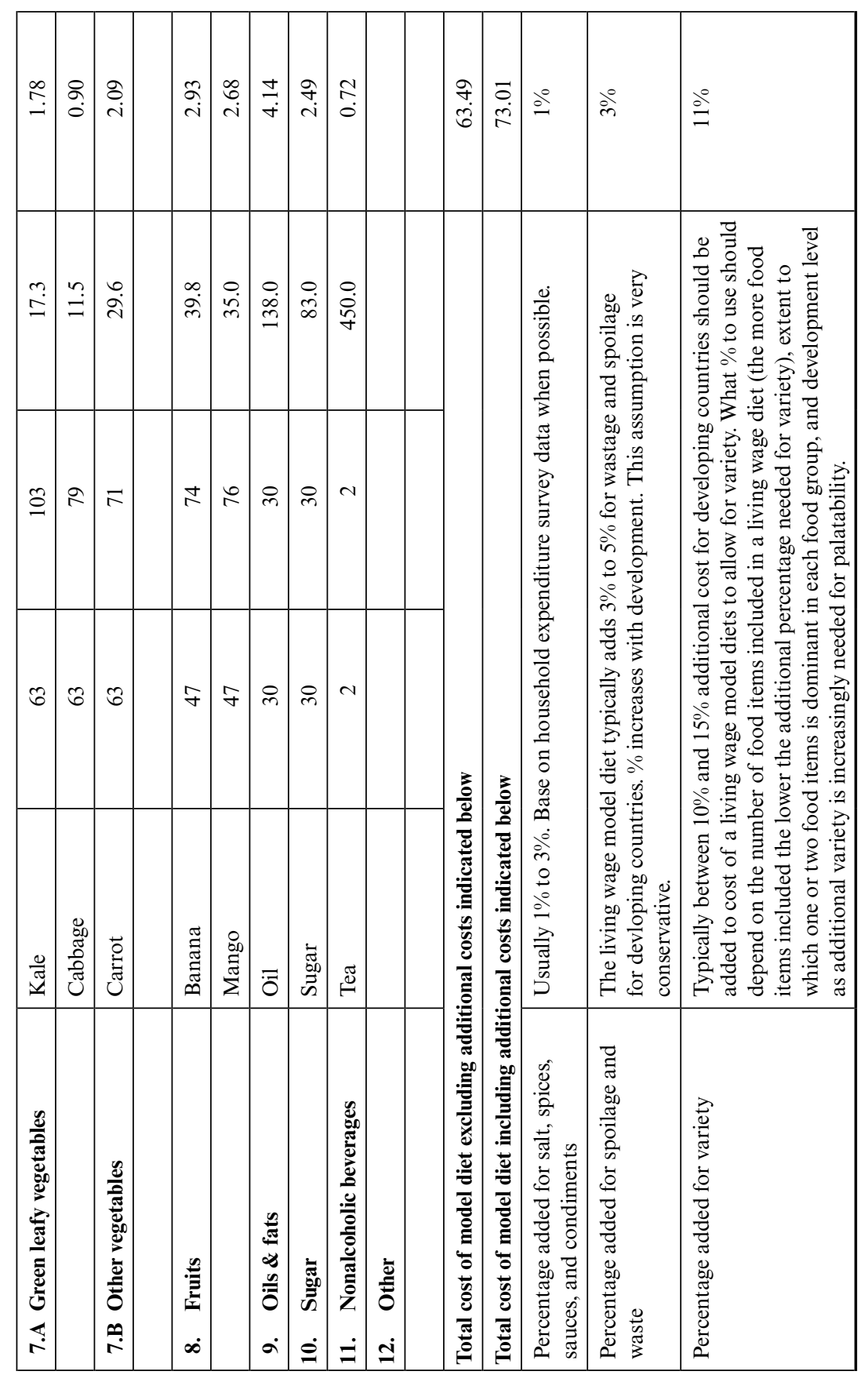




\section{NOTES}

1. WHO/FAO (2003) recommend 400 grams of fruits and vegetables per person per day including legumes - but since this target is not even met in most developed countries, we decided on a minimum of 300 grams (see Section 3.5.1).

2. The body mass indicator (BMI) is equal to weight (in kilos) divided by height squared (in meters). A healthy weight is generally indicated by BMI of 18.5-24.9.

3. See WHO (2004) Table 5.1 for PAR values for a variety of daily activities.

4. Table 3.2 from WHO (2004) is used for energy requirements during first year of life; Table 4.5 is used for energy requirements for boys ages 1-17; and Table 4.6 is used for energy requirements for girls ages $1-17$.

5. This estimate of 1892 calories per child was made using an equal weighting of all ages. This is very similar to the 1875 calories required per child for one child age 6 and one child age 11 with moderate activity.

6. According to WHO (Clugston, n.d.), a breastfeeding mother requires an additional 500 calories per day. Assuming $80 \%$ efficiency in production of breastmilk -400 of the additional calories go to the child and therefore only 100 extra calories per day are required for the family. For a family with 2 children, this amounts to 2.9 additional calories per family member per day over the reproductive years, and 4.3 additional calories for a family with 6 children.

7. Government of India (2010) also has its own equations for BMR, which result in slightly lower energy requirements than those of WHO (2004).

8. It is possible to change BMI in the Excel program when there is a good reason.

9. 1.08 was the median and modal value for 130 locations in Wikipedia (2014). This ratio was between 1.07 and 1.09 for roughly two-thirds of the locations.

10. The EUFIC (2012) review of fruit and vegetable consumption in 19 Western European countries found only 4 countries with average consumption of over 400 grams per day of fruits and vegetables, 7 countries with average consumption of $300-400$ grams, and 8 countries with average consumption less than 300 grams per day. In the United States, median intake of fruits and vegetables in 2011 was 2.6 portions per day for adults and 2.3 portions per day for adolescents, which is around one-half of the recommended 5 portions per day (CDC, 2013).

11. This approach implicitly assumes that: (i) reported number of calories consumed per person increases monotonically with household income (otherwise it might not be possible to unambiguously identify the household income decile or quintile where required number of calories is attained); (ii) reported number of calories consumed per person in the lowest household income decile is less than the required number of calories per person (otherwise lowest income decile or quintile would be the income decile or quintile identified and this would be unfortunate as it would mean that food consumption of very poor persons would be used to set a model diet); and (iii) calorie requirements (which are partly determined by body size and activity level) do not systematically vary by income.

12. There are 'four official USDA food plans. The Thrifty Food Plan serves as a national standard for a nutritious diet at a minimal cost and is used as the basis for maximum food stamp allotments. The Low-Cost, Moderate-Cost, and Liberal Food Plans are used for various purposes: bankruptcy courts often use the Low-Cost Food Plan to determine the portion of a bankrupt person's income to allocate to necessary food expenses. The Department of Defense uses the value of the Liberal Food Plan to determine the Basic Allowance for Subsistence rates for all service members. Many divorce courts use the values of the USDA Food Plans to set alimony payments' (Carlson et al., 2007, p. ES-1).

13. In technical language, 'the model is a constrained nonlinear optimization, with linear constraints and a nonlinear objective function. The model is programmed in the General Algebraic Modeling System and solved sequentially with both the Minos and Conopt solvers' (Carlson et al., 2007, p. A2-1). 
14. An example of how blind use of a linear programming optimization model can lead to senseless results is provided by Chastre et al. (2007, p. 45). They reported that 'in Ethiopia the diet requires enormous quantities of black pepper ... [29 and 27 grams per day in each season for children less than 24 months and 351 and 321 grams in each season for a family of 5 persons] which are unlikely to be consumable in particular for young children.'

15. For example, USDA (Carlson et al., 2007, p. A2-1) relaxed two nutrition requirements ('it is not possible for most baskets to meet RDA [required daily allowance] for vitamin E nor the AI [adequate intake] for potassium). Hence these dietary constraints were relaxed in the models'). In another example where common sense was used, 'consumption constraints are placed on all food groups to prevent the solution from containing an unreasonable amount of food from a single group. These constraints also force a more varied diet than the model would otherwise contain.'

16. In some countries, specific condiments, sauces or spices are important enough to include as a separate food item in the model diet. For example fish sauce in Vietnam and coconut in Sri Lanka are such integral parts of cooking that they were included under 'other' foods in living wage model diets for these countries.

17. For example in Kenya, we estimated what percentage of a mango is edible by weighing several local mangos with and without the pit. In Vietnam and Mauritius, we purchased a variety of vegetables and fish and weighed them before and after workers prepared them for cooking.

18. When relevant data are unavailable, FAOSTAT food balance supply data can be used, but this is a less desirable starting diet because it is based on food availability rather than household consumption. 


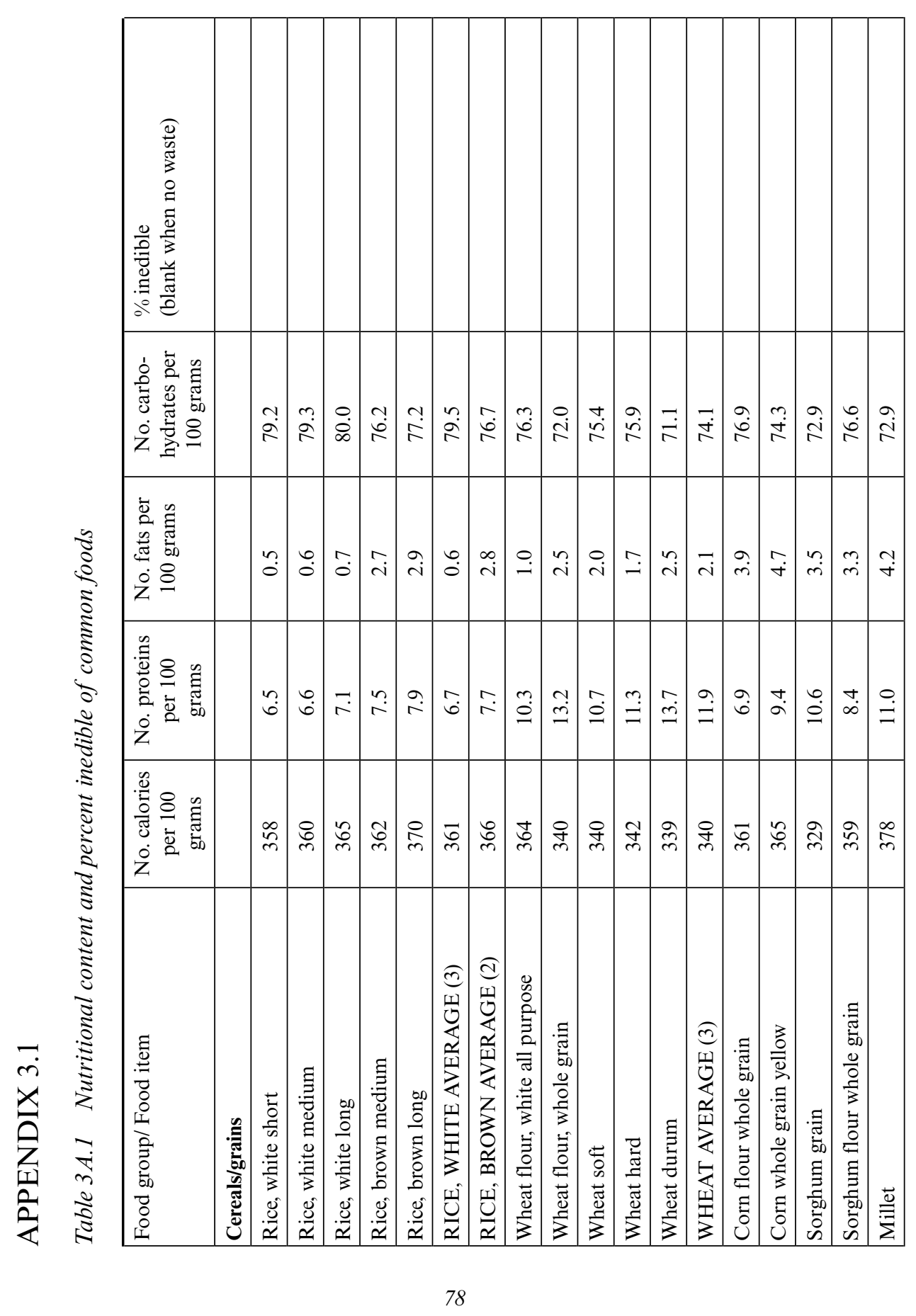




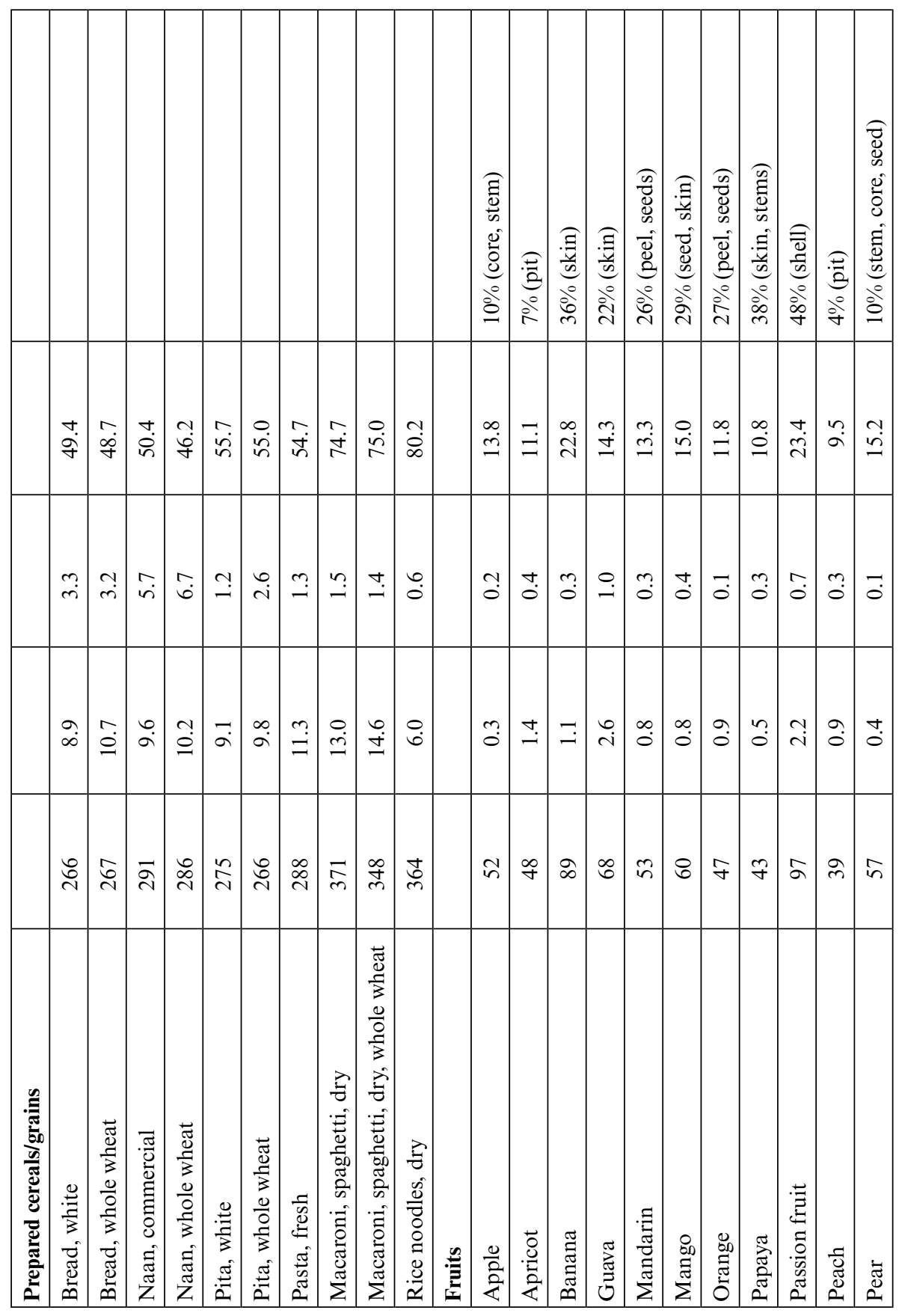




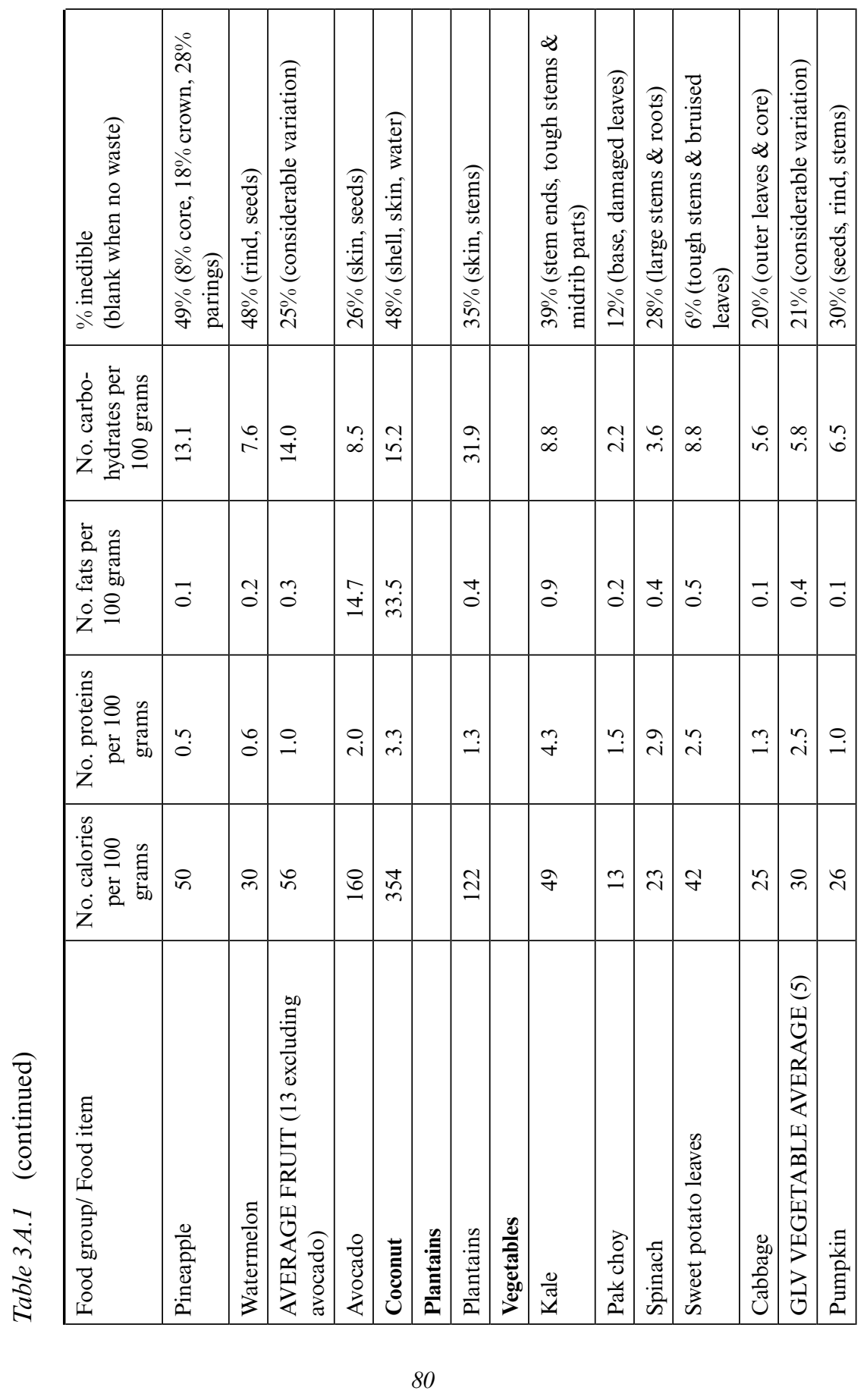




\begin{tabular}{|c|c|c|c|c|c|c|c|c|c|c|c|c|c|c|c|c|c|c|}
\hline 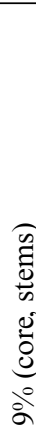 & 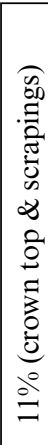 & 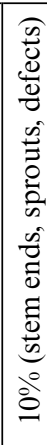 & 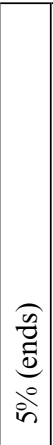 & 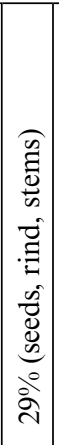 & 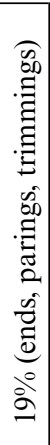 & 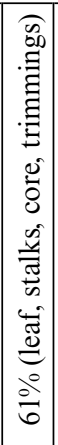 & 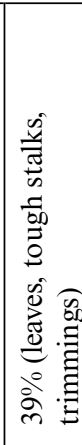 & 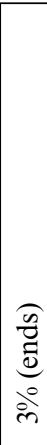 & 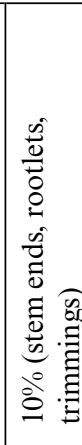 & 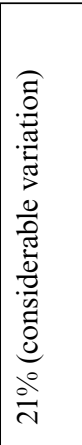 & & 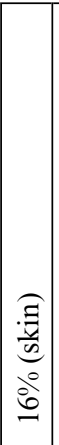 & 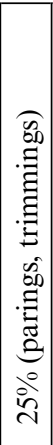 & 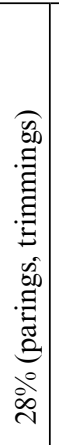 & 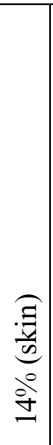 & & 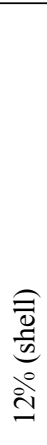 & 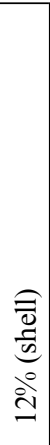 \\
\hline$\hat{\omega}$ & $\stackrel{m}{\sim}$ & $\tilde{a}$ & $\stackrel{+}{\oplus}$ & $\begin{array}{l}0 \\
\infty\end{array}$ & in & in & $\begin{array}{l}0 \\
0\end{array}$ & $\underset{m}{\sigma}$ & $\stackrel{\nabla}{\sim}$ & ণֶ. & & 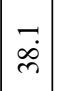 & $\stackrel{n}{=}$ & $\frac{a}{\Delta}$ & $\overrightarrow{\grave{尺}}$ & & $\ddot{0}$ & $\stackrel{n}{n}$ \\
\hline$\stackrel{\text { ஸे }}{0}$ & m. & $\overrightarrow{0}$ & $\stackrel{1}{0}$ & $\overrightarrow{0}$ & $\stackrel{\Upsilon}{0}$ & $\stackrel{m}{0}$ & $\stackrel{+}{\circ}$ & $\overrightarrow{0}$ & $\ddot{0}$ & $\stackrel{\text { ọ }}{0}$ & & $\dddot{m}$ & $\overrightarrow{0}$ & $\overrightarrow{0}$ & $\stackrel{\Upsilon}{0}$ & & $\tilde{a}$ & $\stackrel{\infty}{\stackrel{\sim}{\sim}}$ \\
\hline$\grave{0}$ & $\stackrel{\text { Sִ }}{\longrightarrow}$ & 二 & $\stackrel{\sim}{-}$ & $\stackrel{0}{-}$ & $\stackrel{0}{-}$ & 9 & $\stackrel{\infty}{\sim}$ & $\ddot{0}$ & $\grave{0}$ & $\stackrel{\sim}{-}$ & & $\stackrel{+}{-}$ & $\stackrel{o}{i}$ & $\stackrel{0}{-}$ & $\cong$ & & $\begin{array}{l}0 \\
\stackrel{0}{I}\end{array}$ & $\stackrel{\infty}{\stackrel{d}{J}}$ \\
\hline$\infty$ & in & \& & $\stackrel{0}{0}$ & 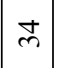 & $\approx$ & $\approx$ & $\ddot{m}$ & 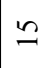 & $\underline{0}$ & $\hat{\sim}$ & & 8 & $\approx$ & $\triangleright$ & $\stackrel{\infty}{=}$ & & $\stackrel{\mathscr{f}}{ \pm}$ & $\infty$ \\
\hline 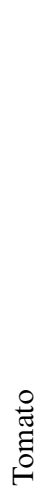 & Uే: & 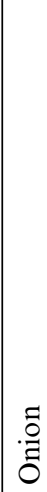 & 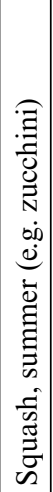 & 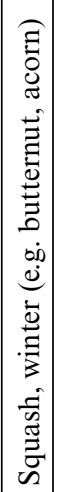 & 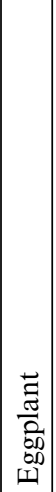 & 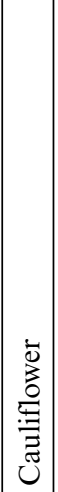 & 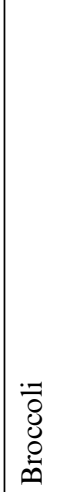 & 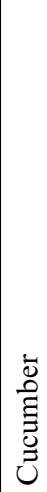 & 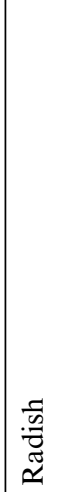 & 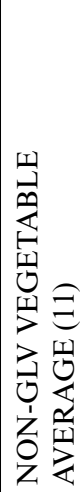 & 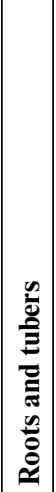 & 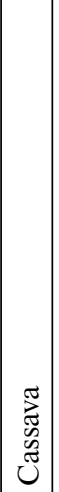 & $\mid$\begin{tabular}{l}
0 \\
\multirow{\pi}{0}{} \\
0 \\
2
\end{tabular} & 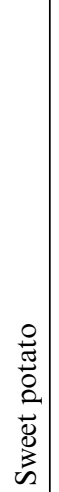 & $\Xi$ & 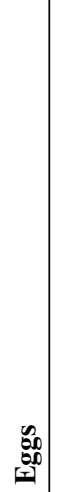 & 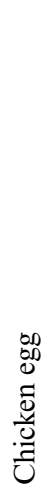 & 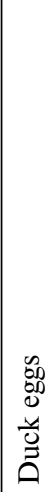 \\
\hline
\end{tabular}




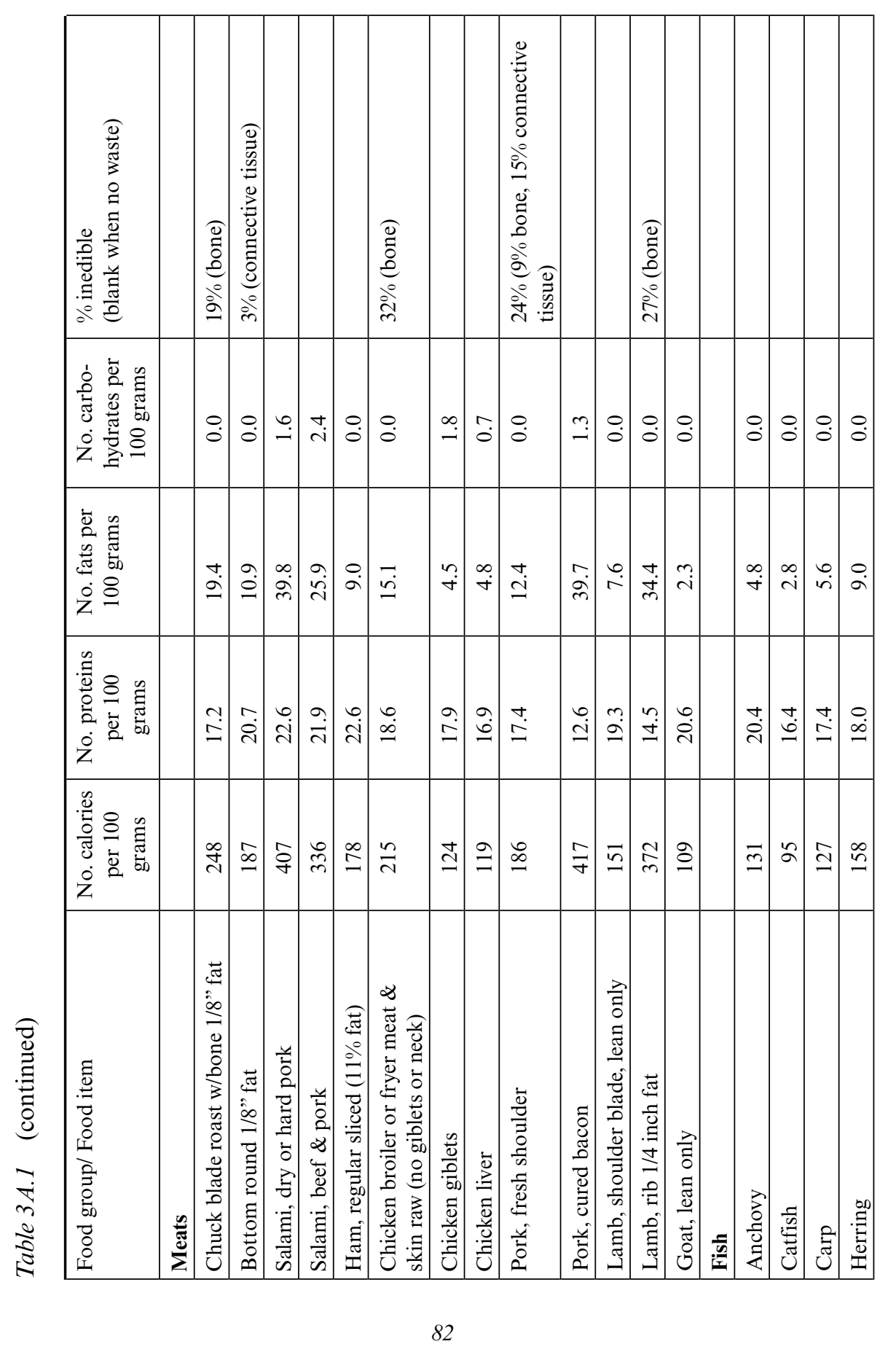




\begin{tabular}{|c|c|c|c|c|c|c|c|c|c|c|c|c|c|c|c|c|c|c|c|c|c|c|}
\hline & & & & & & & & & & 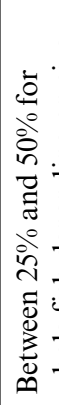 & 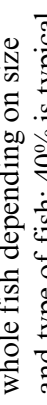 & 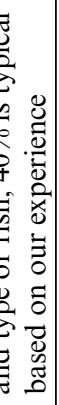 & & & & & & & & & & \\
\hline$\stackrel{\circ}{\circ}$ & $\stackrel{0}{0}$ & $\ddot{\circ}$ & 0 & $\stackrel{0}{0}$ & $\stackrel{0}{0}$ & $\stackrel{0}{0}$ & $\stackrel{0}{0}$ & $\stackrel{0}{0}$ & $\stackrel{0}{0}$ & $\begin{array}{l}0 \\
0\end{array}$ & $\stackrel{0}{0}$ & $\stackrel{\circ}{0}$ & & $\stackrel{0}{0}$ & & $\begin{array}{l}0 \\
\dot{8}\end{array}$ & $\vec{\infty}$ & & $\begin{array}{l}\infty \\
\dot{\forall}\end{array}$ & $\begin{array}{c}\overrightarrow{\dot{D}} \\
\dot{m}\end{array}$ & $\begin{array}{l}0 \\
0\end{array}$ & $\stackrel{\nabla}{\forall}$ \\
\hline$\stackrel{m}{n}$ & $\stackrel{0}{i}$ & $\stackrel{?}{-}$ & $\stackrel{\nabla}{\sim}$ & $\stackrel{a}{i}$ & $\hat{0}$ & $\stackrel{f}{-}$ & $\stackrel{?}{-}$ & $\ddot{\vartheta}$ & ?ֶ: & 9 & $\stackrel{n}{i}$ & $\tilde{a}$ & & $\begin{array}{l}\ddot{8} \\
\dot{8}\end{array}$ & & $\stackrel{0}{0}$ & $\begin{array}{l}0 \\
\dot{0}\end{array}$ & & $m$ & $\hat{\overbrace{}}$ & $\begin{array}{l}0 \\
\sim\end{array}$ & 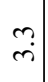 \\
\hline$\stackrel{m}{\infty}$ & $\begin{array}{l}\forall \\
\dot{\infty}\end{array}$ & 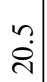 & $\stackrel{+}{\stackrel{8}{0}}$ & $\vec{a}$ & $\stackrel{\infty}{\stackrel{\infty}{\Sigma}}$ & $\overrightarrow{\grave{\lambda}}$ & $\begin{array}{l}+ \\
\infty \\
0\end{array}$ & $\begin{array}{l}0 \\
\infty \\
\infty\end{array}$ & $\stackrel{m}{a}$ & $\begin{array}{l}0 \\
\infty \\
\infty\end{array}$ & $\stackrel{n}{\infty}$ & $\stackrel{n}{2}$ & & $\stackrel{0}{0}$ & & $\stackrel{0}{0}$ & $\overrightarrow{0}$ & & $\stackrel{\sim}{m}$ & 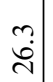 & $\begin{array}{l}\infty \\
0 \\
0\end{array}$ & $\ddot{n}$ \\
\hline ஃ & $\hat{a}$ & 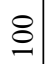 & $\stackrel{\infty}{\infty}$ & $\dot{m}$ & $\infty$ & ঃ & ஓ & $\stackrel{\overbrace{}}{\tilde{N}}$ & $\hat{m}$ & $\stackrel{2}{\simeq}$ & $\overline{0}$ & $\stackrel{\infty}{\varrho}$ & & $\underset{\infty}{+}$ & & $\hat{\infty}$ & 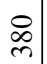 & & $\bar{\sigma}$ & $\stackrel{\circ}{\stackrel{+}{+}}$ & $\dot{m}$ & $\bar{\sigma}$ \\
\hline$: \stackrel{\infty}{\Xi}$ & 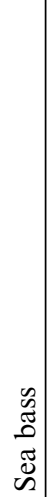 & 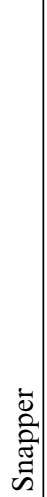 & 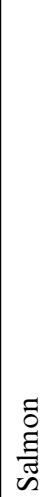 & 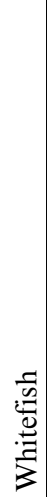 & ن & $\frac{\frac{\pi}{2}}{\frac{\pi}{3}}$ & 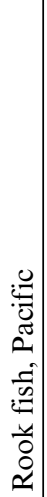 & 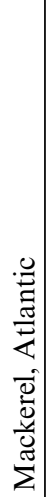 & 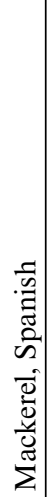 & 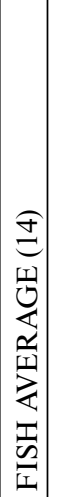 & 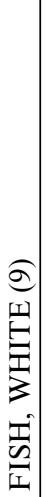 & 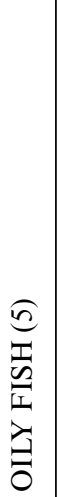 & $\frac{n}{0}$ & 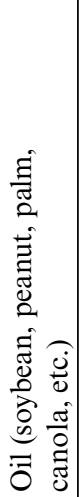 & 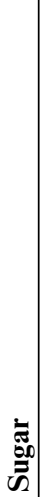 & 兽 & 䓂 & 坣 & 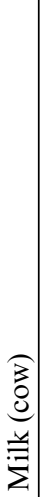 & $\begin{array}{l} \\
\\
\exists \\
\vdots \\
\vdots \\
\vdots\end{array}$ & 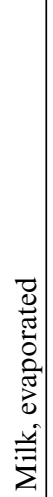 & $\begin{array}{c} \\
\vec{\Xi} \\
0 \\
0 \\
0\end{array}$ \\
\hline
\end{tabular}




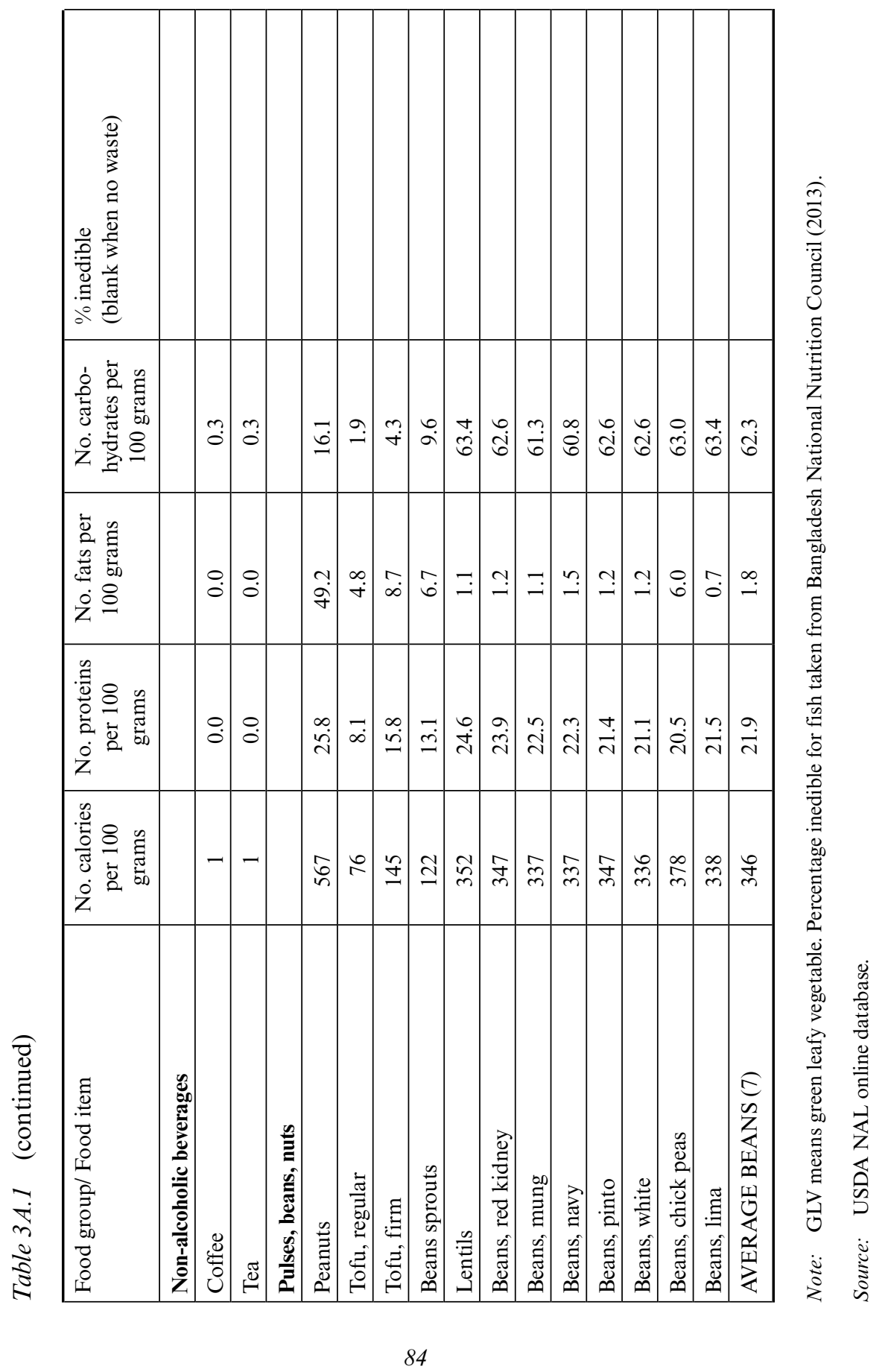




\section{APPENDIX 3.2}

Table 3A.2 Typical sizes of common food items (in purchased grams)

\begin{tabular}{|c|c|c|c|}
\hline Food item & Small & Medium/typical & Large \\
\hline Banana & 158 & 184 & 213 \\
\hline Apple & 166 & 202 & 248 \\
\hline Orange & 107 & 179 & 252 \\
\hline Mandarin & 84 & 119 & 162 \\
\hline Papaya & 174 & - & 1260 \\
\hline Avocado & - & 272 & - \\
\hline Coconut & - & 763 & - \\
\hline Eggplant & - & 677 & - \\
\hline Cauliflower & 294 & 1508 & 2154 \\
\hline Broccoli & - & 997 & - \\
\hline Cucumber & - & 310 & - \\
\hline Radish & 2 & 5 & 10 \\
\hline Onion & 78 & 122 & 167 \\
\hline Tomato & 69 & 135 & 200 \\
\hline Carrot & 56 & 69 & 81 \\
\hline Chicken egg & 42 & 50 & 57 \\
\hline Duck egg & - & 70 & - \\
\hline Bread & - & 29 per slice & - \\
\hline Pita & - & 60 & - \\
\hline Naan & - & 106 & - \\
\hline Cooking oil & - & 13.6 per tablespoon & - \\
\hline Sugar & - & 4.2 per teaspoon & - \\
\hline Milk & - & 244 per cup & - \\
\hline
\end{tabular}

Source: USDA NAL online database. 